This document is the accepted manuscript version of the following article:

Nedyalkova, L., Lothenbach, B., Geng, G., Mäder, U. \& Tits, J. (2020). Uptake of iodide by calcium aluminate phases (AFm phases). Applied Geochemistry, 116, 104559. https://doi.org/10.1016/j.apgeochem.2020.104559 This manuscript version is made available under the CC-BY-NC-ND 4.0 license http://creativecommons.org/licenses/by-nc-nd/4.0/

\title{
Uptake of iodide by calcium aluminate phases (AFm phases)
}

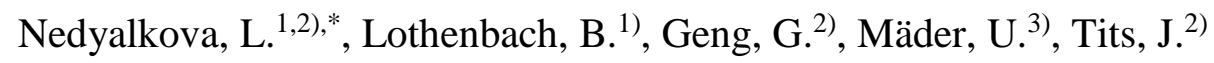

${ }^{1)}$ Laboratory for Concrete and Construction Chemistry, Empa, Dübendorf, Switzerland

${ }^{2)}$ Laboratory for Waste Management, Paul Scherrer Institute, Villigen PSI, Switzerland

${ }^{3)}$ Institute of Geological Sciences, University of Bern, Switzerland

*Corresponding author. E-mail address: latina.nedyalkova@empa.ch; latina_nedyalkova@abv.bg

Keywords: AFm phases, iodine, waste management, solid solution, thermodynamic modelling

\section{Abstract}

Iodine-129 is an important dose-determining radionuclide emanating from low and intermediate level radioactive waste (L/ILW) repositories. A good candidate for the immobilization of the hazardous $\mathrm{I}^{-}$anions are AFm phases due to their interlayer anion exchange capacity.

The ability of AFm phases to bind iodine was investigated in a set of co-precipitation experiments, in which the formation of solid solutions between the iodine AFm end member monoiodide (I-AFm) and the common AFm phases hemicarbonate $\left(\mathrm{OH}, \mathrm{CO}_{3}-\mathrm{AFm}\right)$, monocarbonate $\left(\mathrm{CO}_{3}-\mathrm{AFm}\right)$ and hydroxy-AFm $(\mathrm{OH}-\mathrm{AFm})$, was examined. The samples were characterized by TGA, FTIR, XRPD and liquid phase analyses, and the obtained data were used to construct solid solution models with the help of the thermodynamic modelling program GEMS. The formation of extensive solid solutions was found between the AFm end member pairs monoiodide and hydroxy-AFm, and monoiodide and hemicarbonate. In these two cases, the progressive substitution of the interlayer anion is reflected by a gradual change of the interlayer distance, visible by a continuous peak shift of the basal reflexion from one end member towards the other. No solid solution forms between the end members monoiodide and monocarbonate. In the presence of small amounts of carbonate, a mixed $\left(\mathrm{I}, \mathrm{OH}, \mathrm{CO}_{3}\right)-\mathrm{AFm}$ phase precipitates, similar to the one found in the monoiodide-hemicarbonate set of experiments, indicated by the similarity in the observed d-values. With increasing carbonate concentration, monocarbonate is stabilized.

The experimental data suggests that iodine can be incorporated in the AFm interlayer where anion exchange leads to the formation of solid solutions. The solid solution formation is favoured only between end members with similar crystal symmetry. The presence of carbonate favours the formation of monocarbonate in the long term, reducing the capability of AFm phases to immobilize iodide. 


\section{Introduction}

Iodine-129 is a long-lived radionuclide (with a half-life of $1.57 \times 10^{7}$ a) present in low and intermediate level radioactive waste (L/ILW) and therefore of importance with a view to the safe disposal of this kind of waste (NAGRA 2002). Under the alkaline $(10<\mathrm{pH}<13.5)$ and reducing conditions $\left(-750 \mathrm{mV}<\mathrm{E}_{\mathrm{h}}<-230 \mathrm{mV}\right.$ (SHE)) expected in the near-field of a cementbased L/ILW repository (Wersin et al. 2003), the thermodynamically stable iodine species is iodide $\left(\mathrm{I}^{-}\right)$. The migration of the $\mathrm{I}^{-}$anions through the repository near-field can be retarded by sorption on the cementitious materials used for the construction of the engineered barrier system. Amongst the components of the cementitious matrix, $\mathrm{AFm}\left(\mathrm{Al}_{2} \mathrm{O}_{3}-\mathrm{Fe}_{2} \mathrm{O}_{3}\right.$-mono) phases are the minerals with the highest sorption capacity for I' (Atkins and Glasser 1992). AFm phases are a group of layered calcium aluminate-ferrite double hydroxides (LDH family) with the general formula $\left[\mathrm{Ca} 4(\mathrm{Al}, \mathrm{Fe})_{2}(\mathrm{OH})_{12}\right] \cdot \mathrm{X} \cdot n \mathrm{H}_{2} \mathrm{O}$. The structure is built by octahedral calcium-aluminium hydroxide layers with a $\mathrm{Ca}^{2+}: \mathrm{Al}^{3+}\left(\mathrm{Fe}^{3+}\right)$ ratio of 2:1 $\left(\left[\mathrm{Ca}_{4}(\mathrm{Al}, \mathrm{Fe})_{2}(\mathrm{OH})_{12}\right]^{2+}\right)$, alternating with interlayers containing charge-balancing $\mathrm{X}$ anions and water molecules $\left(\left[\mathrm{X} \cdot n \mathrm{H}_{2} \mathrm{O}\right]^{2-}\right)$ (Taylor 1997). The type of the $\mathrm{X}$ anion and the amount of interlayer water $n$ determine the layer thickness (Taylor 1997, Baquerizo et al. 2015). A variety of mono- or divalent anions can serve as $\mathrm{X}$ depending on the cement composition and the service environment (e.g. repository nearfield), the most common ones being $\mathrm{CO}_{3}{ }^{2-}, \mathrm{OH}^{-}, \mathrm{SO}_{4}{ }^{2-}$ and $\mathrm{Cl}^{-}$(Evans and Slade 2006, Matschei et al. 2007a). An AFm phase may also contain more than one type of interlayer anions, leading to the formation of solid solutions (Glasser et al. 1999, Matschei et al. 2007a).

The high interlayer anion exchange capacity of AFm phases makes them a suitable candidate for the immobilization of the $\mathrm{I}^{-}$anions. A number of studies have been carried out investigating the structural incorporation of $\mathrm{I}^{-}$in the AFm interlayer (Brown and Grutzeck 1985, Rapin et al. 1999, Toyohara et al. 2000, Aimoz et al. 2012a). The existence of a stable monoiodide (I-AFm) phase with the composition $3 \mathrm{CaO} \cdot \mathrm{Al}_{2} \mathrm{O}_{3} \cdot \mathrm{CaI}_{2} \cdot 10 \mathrm{H}_{2} \mathrm{O}$ has been confirmed and its structure solved in the trigonal R-3H space group with an interlayer spacing of $8.84 \AA$ (Rapin et al. 1999). The synthesis of bianionic AFm phases containing a mixture of $\mathrm{I}^{-}$and another type of anion in the interlayer have also been attempted, showing that the incorporation of $\mathrm{I}^{-}$is dependent on the type of the competing anion. The I-AFm phase was found to form continuous solid solutions with the Br-AFm (Kuzel 1971) and the $\mathrm{SO}_{4}$-AFm (monosulfate) (Kuzel 1971, Aimoz et al. 2012a, 2012b). The thermodynamic properties of the (I,SO 4$)$-AFm solid solution were also determined (Aimoz et al. 2012b). On the other hand, the presence of $\mathrm{Cl}^{-}$favours the precipitation of Cl-AFm (Friedel's salt) in coexistence with an I-AFm rather than forming a solid solution (Kuzel 1971, Aimoz et al. 2012a). In the case of $\mathrm{CO}_{3}{ }^{2-}$ as the competitive anion, Aimoz et al. 
(2012a) observed destabilization of the I-AFm and its partial recrystallization into $\mathrm{CO}_{3}$-AFm (monocarbonate) in a set of experiments, where $\mathrm{CO}_{3}{ }^{2-}$ was added to an I-AFm suspension. In co-precipitation experiments, however, the same authors found the formation of a mixed AFm phase with two distinct types of interlayer regions - one filled by $\mathrm{I}^{-}$only and another one by $\mathrm{OH}^{-}$and $\mathrm{CO}_{3}{ }^{2-}$ (corresponding to hemicarbonate, an $\left.\left(\mathrm{OH}, \mathrm{CO}_{3}\right)-\mathrm{AFm}\right)$; stacked sequentially in an almost regular pattern. The resulting AFm phase had an interlayer distance of $17.01 \AA$, consistent with the interstratification of I-AFm and $\left(\mathrm{OH}, \mathrm{CO}_{3}\right)$-AFm. Such stacking effect has also been reported for Kuzel's salt, an $\left(\mathrm{Cl}, \mathrm{SO}_{4}\right)-\mathrm{AFm}$, whose structure is composed of the intercalation of the two end members $\mathrm{Cl}-\mathrm{AFm}$ and $\mathrm{SO}_{4}-\mathrm{AFm}$ (Mesbah et al. 2011a).

Modern cements contain in addition to cement clinkers and calcium sulfate, also limestone, which prevents the formation of monosulfate $\left(\mathrm{SO}_{4}-\mathrm{AFm}\right)$, while initially hemicarbonate $\left(\mathrm{OH}, \mathrm{CO}_{3}-\mathrm{AFm}\right)$, and later monocarbonate $\left(\mathrm{CO}_{3}-\mathrm{AFm}\right)$ is formed (Lothenbach et al. 2008, Zajac et al. 2014). Thus, the present study concentrates on I' uptake by AFm phases in competition with $\mathrm{CO}_{3}{ }^{2-}$ and/or $\mathrm{OH}^{-}$and the possible formation of solid solutions between the different $\mathrm{AFm}$ end members. A short summary of the AFm phases occurring in the $\mathrm{CaO}-\mathrm{Al}_{2} \mathrm{O}_{3}-\left(\mathrm{CO}_{2}\right)-\mathrm{H}_{2} \mathrm{O}$ system and their relevant characteristics follows. Monocarbonate (Mc), with the chemical formula $3 \mathrm{CaO} \cdot \mathrm{Al}_{2} \mathrm{O}_{3} \cdot \mathrm{CaCO}_{3} \cdot 11 \mathrm{H}_{2} \mathrm{O}$, has a triclinic symmetry and two known structures - an ordered one with the P1 space group (Francois et al. 1998) and a disordered structure described in the P-1 space group (Renaudin et al. 1999). The $\mathrm{CO}_{3}{ }^{2-}$ anions from the interlayer are connected to the $\mathrm{Ca}^{2+}$ from the main layer via shared oxygens belonging to the carbonate group, thus resulting in a very rigid structure and a narrow interlayer distance of $7.55 \AA$ (Francois et al. 1998). In the hemicarbonate (Hc) structure half of the carbonate in the interlayer is replaced by hydroxyl groups $\left(\mathrm{OH}^{-}\right)$corresponding to the formula $3 \mathrm{CaO} \cdot \mathrm{Al}_{2} \mathrm{O}_{3} \cdot 0.5\left(\mathrm{Ca}(\mathrm{OH})_{2}\right) \cdot 0.5\left(\mathrm{CaCO}_{3}\right) \cdot 11.5 \mathrm{H}_{2} \mathrm{O}$. The interlayer anions are bonded only weakly to the main layer by hydrogen bonds, giving rise to a different crystal symmetry (trigonal, R-3cH space group) and larger interlayer distance $(d=8.20 \AA$ ) (Runčevski et al. 2012). In the presence of carbonate concentrations above the stability limit for hemicarbonate, it is unstable and slowly transforms to monocarbonate (Kuzel and Pöllmann 1991, Lothenbach et al. 2008). As an intermediate product of this transformation another phase can form - the carbonated hemicarbonate $(\mathrm{cHc})$, which is characterized by a higher $\mathrm{CO}_{3}{ }^{2-}$ and lower $\mathrm{OH}^{-}$content in the interlayer compared to hemicarbonate (Runčevski et al. 2012). The AFm end member with the interlayer fully occupied by $\mathrm{OH}^{-}$anions is the hydroxy-AFm $(\mathrm{OH}-\mathrm{AFm})$ with the formula $4 \mathrm{CaO} \cdot \mathrm{Al}_{2} \mathrm{O}_{3} \cdot x \mathrm{H}_{2} \mathrm{O}$. Depending on the relative humidity and exposure temperature, several hydrates of $\mathrm{OH}-\mathrm{AFm}$ can exist with $x$ equal to 7, 11, 13 or 19 and interlayer distances of 
$5.60 \AA(\mathrm{OH}-\mathrm{AFm} 7), 7.35 \AA$ (OH-AFm11), $7.94 \AA$ (OH-AFm13) and $10.70 \AA(\mathrm{OH}-\mathrm{AFm} 19)$, respectively (Aruja 1961, Fischer and Kuzel 1982, Baquerizo et al. 2015). The OH-AFm19 structure is described in the trigonal R-3c space group (for the $\alpha_{1}$ polymorph (Aruja 1961)), which space group is also assumed for all other hydrates. OH-AFm is metastable and decomposes to a mixture of katoite $\left(\mathrm{Ca}_{3} \mathrm{Al}_{2}(\mathrm{OH})_{12}\right)$ and portlandite $\left(\mathrm{Ca}(\mathrm{OH})_{2}\right)$ at temperatures above $20^{\circ} \mathrm{C}$ (Lothenbach et al. 2012).

Although the interaction between $\mathrm{I}^{-}$and $\mathrm{CO}_{3}{ }^{2-}$ in the AFm interlayers has been studied before (Aimoz et al. 2012a), no solubility data were determined and ternary $\mathrm{I}^{-}, \mathrm{OH}^{-}, \mathrm{CO}_{3}{ }^{2-}$ mixtures in AFm interlayers were not considered. To fill this gap, co-precipitation experiments with different concentrations of $\mathrm{I}^{-}$and its competitor anions $\mathrm{CO}_{3}{ }^{2-}$ and/or $\mathrm{OH}^{-}$were performed. Characterization of the solids and their solubility properties were used for the construction of solid solution models between I-AFm and the AFm phases mono-, hemicarbonate and hydroxy-AFm more commonly found in hydrated cements.

\section{Materials and Methods}

\subsection{AFm synthesis and characterization}

All sample manipulations were performed in a $\mathrm{N}_{2}$-filled glove box to minimize atmospheric $\mathrm{CO}_{2}$ contamination. Solutions were prepared using high-purity deionized water (resistivity = 18.2 $\mathrm{M} \Omega \mathrm{cm}$ ) generated by a Milli-Q Gradient A10 System (Millipore, Bedford, USA). All chemicals were analytical grade reagents. The following chemicals were used: $\mathrm{CaO}, \mathrm{Al}_{2} \mathrm{O}_{3}$, $\mathrm{CaCO}_{3}, \mathrm{Na}_{2} \mathrm{CO}_{3}, \mathrm{NaI}$, and $\mathrm{CaI}_{2}$ (Sigma-Aldrich, St. Louis, Missouri, USA). Tricalcium aluminate $\left(\mathrm{C}_{3} \mathrm{~A}\right)$ was prepared by mixing appropriate amounts of $\mathrm{CaCO}_{3}$ with $\mathrm{Al}_{2} \mathrm{O}_{3}$ powder to achieve a molar ratio of $3: 1$ and by heating the mixture at $800^{\circ} \mathrm{C}$ for $1 \mathrm{~h}$, at $1000^{\circ} \mathrm{C}$ for another $4 \mathrm{~h}$ and finally at $1425^{\circ} \mathrm{C}$ for $24 \mathrm{~h}$. The clinker material was then ground to $<63 \mu \mathrm{m}$. To ensure that no $\mathrm{CO}_{2}$ contamination of $\mathrm{CaO}$ occurred, the latter compound was heated at $900^{\circ} \mathrm{C}$ for $12 \mathrm{~h}$ prior to the synthesis.

The solid solution series were synthesized by mixing stoichiometric amounts of the starting powder materials $\mathrm{C}_{3} \mathrm{~A}, \mathrm{CaO}$, and the appropriate $\mathrm{Na}_{(2)}-\mathrm{X}(\mathrm{pH} 13)$ or $\mathrm{Ca}-\mathrm{X}(\mathrm{pH} \sim 12)$ salt in MilliQ water or $\mathrm{NaOH}$ solution. The goal was to obtain different total iodide mole fractions $\left(x_{\mathrm{I}}\right.$ $\left.=\mathrm{I}^{-} /\left(\mathrm{I}^{-}+\mathrm{X}^{n-}\right)=0,0.1,0.3,0.5,0.7,0.9,1\right)$ with $\mathrm{X}^{n-}=\mathrm{OH}^{-}$and $/$or $\mathrm{CO}_{3}{ }^{2-}$ for hemicarbonate, monocarbonate and hydroxy-AFm. 
The samples were equilibrated for three months, in closed PE-bottles at $20^{\circ} \mathrm{C}$ on end-over-end shakers $(100 \mathrm{rpm})$. After equilibration, the solid and liquid phases were separated by vacuum filtration through a $0.45 \mu \mathrm{m}$ nylon filter. The solid phases were dried in a desiccator over a saturated $\mathrm{NaOH}$ solution ( $\sim 8 \%$ relative humidity) at room temperature for five to six weeks under initial vacuum.

After drying, the solids were analysed by X-ray powder diffraction (XRPD), thermogravimetric analysis (TGA) and infrared (FTIR) spectroscopy. XRPD analyses were performed on a PANalytical X'Pert Pro MPD diffractometer using CuK $\alpha$ radiation $(\lambda=1.54184 \AA)$; the diffraction patterns were recorded between $5<2 \theta<70^{\circ}$ with a step size of $0.017^{\circ}(2 \theta)$ and a counting time of 0.6 s per step. Rietveld refinement was conducted using the collected XRPD data of the solid solution samples between monoiodide and hemicarbonate synthesized at $\mathrm{pH} \sim 12$, in order to quantify the evolution of the crystal structure as a function of increasing $\mathrm{I}^{-}$substitution of the $\mathrm{OH}^{-} / \mathrm{CO}_{3}{ }^{2-}$ groups. In the hemicarbonate structure with the symmetry $\mathrm{R}-3 \mathrm{c}$, the interlayer hosts $\mathrm{OH}^{-} / \mathrm{CO}_{3}{ }^{2-}$ at the 6 -multiplicity symmetry sites with the primary atomic position $2 / 3,1 / 3,1 / 12$ (Runčevski et al. 2012). For samples with increasing monoiodide mole fraction $x_{\mathrm{I}}$, first a homogeneous substitution of the interlayer anion group $\left(\mathrm{CO}_{3}{ }^{2-}\right.$ or $\left.\mathrm{OH}^{-}\right)$by $\mathrm{I}^{-}$was considered, where $\mathrm{I}^{-}$is placed right on the 6-multiplicity site (occupied by $\mathrm{C}^{4+}$ in hemicarbonate) using the configuration published by Rapin et al. (1999). Refinement using this strategy was then compared with the AFm model published in literature, in which the crystal structure of the I-substituted AFm is an alternating layer stacking of hemicarbonate with I-AFm (Aimoz et al. 2012a). Apart from AFm, katoite was also detected by XRPD and its component refined for each sample. The refinement was conducted using the MAUD package (Lutterotti et al. 1999). The experimental condition of the $\mathrm{Cu}$-source lab-XRD was defined via refining the line-broadening parameters using reference data of a $\mathrm{CaF}_{2}$ standard. Considering the platy morphology of $\mathrm{AFm}$ crystals, the crystallite size was described by a two-parameter-Popa model (Lutterotti et al. 1999). It was noted that the (l $\left.\begin{array}{lll}0 & 3\end{array}\right)$ and ( $\left.\begin{array}{lll}0 & 0 & 6\end{array}\right)$ diffraction peaks are overwhelmingly strong for some samples, which is most likely due to preferred orientation. Therefore a standard fibre function was used to describe the orientation in the MAUD refinement (Lutterotti et al. 2004, Geng et al. 2018). The lattice parameters and the proportion of $\mathrm{I}^{-}$substitution were the key information to be fitted from the refinement.

The water content of the solids was determined by TGA measurements, carried out on a TGA/SDTA 851 instrument (Metter Toledo, Switzerland). The samples ( 15 mg) were heated under a $\mathrm{N}_{2}$ atmosphere over the temperature range between 30 and $980^{\circ} \mathrm{C}$ at a heating rate of $20^{\circ} \mathrm{C} / \mathrm{min}$. For the calculation of the structural water, the temperature range between $30^{\circ} \mathrm{C}$ and 
$\sim 425^{\circ} \mathrm{C}$ was considered only as mass losses above $\sim 425^{\circ} \mathrm{C}$ are associated with the removal of $\mathrm{CO}_{2}$ and possibly $\mathrm{HI}$ or $\mathrm{I}_{2}$. Attenuated total reflectance infrared spectra were recorded in the 4000 to $600 \mathrm{~cm}^{-1}$ range on a Bruker Tensor 27 FTIR spectrometer to investigate the absorption bands caused by the carbonate group and the hydrogen bond network.

Immediately after filtration, the $\mathrm{pH}$ was measured using a Knick pH-meter with a SE $100 \mathrm{pH} / \mathrm{Pt}$ 1000 electrode (Knick, Germany) at room temperature. The electrode was calibrated with $\mathrm{NaOH}$ solutions of known concentrations to minimize the alkali error caused by the presence of high Na concentrations (Traynor et al. 2019). The chemical composition of the liquid phases was analysed with a Dionex ICS-3000 ion chromatography system equipped with a Dionex Ion Pac AS25 column for I; a Dionex Ion Pac CS12A column for Na and Ca; and a Dionex Ion Pac CS5A column for Al. The eluents used were $37 \mathrm{mM} \mathrm{NaOH}$ solution for I, $1.3 \mathrm{ml}$ of $\geq 99.5 \%$ methanesulfonic acid (MSA) per litre water for $\mathrm{Na}$ and $\mathrm{Ca}$, and $74 \mathrm{ml}$ of $32 \% \mathrm{HCl}$ per litre water for Al, respectively (Nedyalkova et al. 2019). The dissolved Al concentrations were quantified in the undiluted solutions; for $\mathrm{I}, \mathrm{Na}$ and $\mathrm{Ca}$ in the case of the $\mathrm{pH} \sim 12$ samples, the samples were diluted by a factor of 1:100. Total inorganic carbon was analysed using a Sievers $5310 \mathrm{C}$ TOC Analyzer equipped with a Sievers 900 Autosampler (GE Analytical Instruments, USA).

\subsection{Data interpretation}

The measured ion concentrations and $\mathrm{pH}$ values in the equilibrium solution were used to calculate the solubility products of the synthesized AFm phases using the thermodynamic modelling program GEMS (Kulik et al. 2013) and the NAGRA/PSI database (Thoenen et al. 2014), including a full speciation calculation. The activity coefficients of the aqueous species were calculated with the built-in extended Debye-Hückel equation. First, the solubility products $(\log K)$ of the four end members - I-AFm, hemi-, monocarbonate and $\mathrm{OH}-\mathrm{AFm}$ were determined referring to $\mathrm{Ca}^{2+}, \mathrm{AlO}_{2}{ }^{-}, \mathrm{H}_{2} \mathrm{O}, \mathrm{CO}_{3}{ }^{2-}, \mathrm{OH}^{-}$and $\mathrm{I}^{-}$, respectively and solids with $4 \mathrm{Ca}$ within the main layer. For the calculations, the highest possible hydration state of each phase was considered, i.e. $19 \mathrm{H}_{2} \mathrm{O}$ for OH-AFm (Aruja 1961) and $15 \mathrm{H}_{2} \mathrm{O}$ for I-AFm (as determined by dynamic vapour sorption experiments (DVS) in this study; Fig. A.1) - e.g. $K_{\mathrm{s} 0}(\mathrm{I}-\mathrm{AFm})=\left\{\mathrm{Ca}^{2+}\right\}^{4}\left\{\mathrm{AlO}_{2}^{-}\right.$ \}$^{2}\left\{\mathrm{I}^{-}\right\}^{2}\left\{\mathrm{OH}^{-}\right\}^{4}\left\{\mathrm{H}_{2} \mathrm{O}\right\}^{13}$ for the I-AFm end member where \{\} denote activity. In the $\mathrm{pH} \sim 13$ samples belonging to the monoiodide-hemicarbonate and monoiodide-monocarbonate solid solution series, measured carbon concentrations were below the detection limit and solubility products were calculated assuming equilibrium conditions with monocarbonate in the case of the hemicarbonate-containing samples and calcite in the case of the monocarbonate-containing samples. 
Solubility data of the solid solution series are visualized in the form of Lippmann diagrams, in which the compositions of the liquid and the solid phase in equilibrium with one another are plotted against the total solubility product $\Sigma \Pi$ (Lippmann 1980). $\Sigma \Pi$ of a binary solid solution is defined as the sum of the partial solubility products of each end member (e.g. $\left.\Sigma \Pi\left(\left(\mathrm{I}, \mathrm{OH}, \mathrm{CO}_{3}\right)-\mathrm{AFm}\right)\right)=\left\{\mathrm{Ca}^{2+}\right\}^{4}\left\{\mathrm{AlO}_{2}^{-}\right\}^{2}\left[\left\{\mathrm{I}^{-}\right\}^{2}+\left\{\mathrm{CO}_{3}{ }^{2-}\right\}^{0.5}+\left\{\mathrm{OH}^{-}\right\}\right]\left\{\mathrm{OH}^{-}\right\}^{4}\left\{\mathrm{H}_{2} \mathrm{O}\right\}^{12}$ for a sample belonging to the monoiodide-hemicarbonate solid solution series). On a Lippmann diagram, the composition of the solid is represented by the solidus line; the liquid phase composition by the solutus line. The shape of both curves is dependent on the selected solid solution model and the non-ideality of mixing. In the case of non-ideal mixing, the Redlich-Kister (Redlich and Kister 1948) sub-regular model was applied, in which the total Gibbs energy G of a system is defined as:

$$
G=\sum_{i} x_{i} \mu_{i}^{\circ}+R T \sum_{i} x_{i} \ln X_{i}+R T \sum_{i} x_{i} \ln \gamma_{i}
$$

with $x_{\mathrm{i}}=$ mole fraction of the end member $\mathrm{i} ; \mu_{\mathrm{i}}=$ chemical potential of $\mathrm{i} ; R=$ universal gas constant; $T=$ temperature and $\gamma_{i}=$ activity coefficient of the end member $i$. The activity coefficients can be fitted using the following equations:

$$
\ln \gamma_{1}=x_{2}^{2}\left(a_{0}+a_{1}\left(4 x_{1}-1\right)\right) \text { and } \ln \gamma_{2}=x_{1}^{2}\left(a_{0}-a_{1}\left(4 x_{2}-1\right)\right)
$$

where $a_{\mathrm{i}}$ are the dimensionless Guggenheim parameters (Glynn 2000). The end member mole fraction in the solid $x_{\mathrm{i}}$ in the case of the monoiodide-hemicarbonate series was obtained by Rietveld refinement of the XRPD data. For the monoiodide-hydroxy-AFm and monoiodidemonocarbonate series, $x_{\mathrm{i}}$ was determined by mass balance calculations based on the difference in the I:Al and I:Ca ratios between the initial concentrations in the samples and the measured concentrations in solution after filtration. In the monoiodide-hydroxy-AFm series, significant katoite $\left(\mathrm{Ca}_{3} \mathrm{Al}_{2}(\mathrm{OH})_{12}\right)$ impurities were detected in some of the samples and a correction was applied. This was done by estimating the amount of katoite from TGA analyses. The $x_{\mathrm{i}}$ values for monoiodide-hydroxy-AFm and monoiodide-monocarbonate series are associated with a large error of about $10 \%$, in particularly for the cases when secondary phases were present.

In the studied system, an interlayer anion exchange between $\mathrm{I}^{-}$and $\mathrm{CO}_{3}{ }^{2-} / \mathrm{OH}^{-}$takes place, i.e. in some cases a substitution by heterovalent anions ( $1^{-}$vs. $\left.2^{-}\right)$needs to be taken into account. The exchange reaction can be described using the Vanselow convention (Vanselow 1932) as a substitution of one mole $\mathrm{CO}_{3}{ }^{2-}$ for one mole of $\mathrm{I}^{-}$, regardless of their charge. A thermodynamic solid solution model based on the Vanselow convention has been shown to adequately describe the mixing between monoiodide and monosulfate, where a heterovalent substitution of $\mathrm{I}^{-}$for $\mathrm{SO}_{4}{ }^{2-}$ takes place (Aimoz et al. 2012b). Following the Vanselow convention, the end members 
are defined as $\mathrm{Ca}_{2} \mathrm{AlI}(\mathrm{OH})_{6} \cdot 4.5 \mathrm{H}_{2} \mathrm{O}$ and $\mathrm{Ca}_{4} \mathrm{Al}_{2}\left(\mathrm{CO}_{3}\right)_{0.5}(\mathrm{OH})_{13} \cdot 5.5 \mathrm{H}_{2} \mathrm{O}$ in the case of the monoiodide-hemicarbonate solid solution series. Lippmann diagrams using both, an ideal solid solution model and a sub-regular model with Guggenheim parameters obtained through best fit of experimental data were constructed and compared (see section 3.2.) to find the model which best describes the studied solid solution series.

\section{Results and discussion}

\subsection{AFm end members}

The synthesized monoiodide, monocarbonate, hemicarbonate and hydroxy-AFm phases were characterized by XRPD, TGA and liquid phase analyses to confirm the formation of the desired AFm end members. In addition, the effect of $\mathrm{pH}(\sim 12$ and $\sim 13)$ on their properties was studied. The tendency of the different AFm to incorporate $\mathrm{I}^{-}$is described in the subsequent section (3.2.).

\section{$\underline{\text { 3.1.1 Monoiodide }}$}

The XRPD powder pattern of an I-AFm sample synthesized at $\mathrm{pH} 13$ was refined using the known crystal structure of monoiodide (Rapin et al. 1999) and by placing the $\mathrm{I}^{-}$anions right on the 6-multiplicity site (primary atomic position $2 / 3,1 / 3,1 / 12$ ) in the interlayer (Fig. 1). The refined interlayer distance is $8.86 \AA$ for a composition $3 \mathrm{CaO} \cdot \mathrm{Al}_{2} \mathrm{O}_{3} \cdot \mathrm{CaI}_{2} \cdot 11 \mathrm{H}_{2} \mathrm{O}$. The presence of about $20 \%$ of katoite impurities was also detected. The sample is slightly more hydrated than monoiodide reported in literature (Rapin et al. 1999) $\left(11 \mathrm{H}_{2} \mathrm{O}\right.$ vs. $10 \mathrm{H}_{2} \mathrm{O}$ per formula unit), which seems to be an effect of the $\mathrm{pH}$ (Fig. 2). When comparing samples synthesized at $\mathrm{pH} \sim 12$ and $\mathrm{pH} 13$, a slight shift of the main diffraction peak towards higher $2 \theta$ values (from $10.02 \theta$ $\mathrm{Cu} \mathrm{K \alpha}(\mathrm{d}=8.8 \AA)$ to $10.22 \theta \mathrm{Cu} \mathrm{K \alpha}(\mathrm{d}=8.6 \AA)$ in the unrefined data $)$ is observed suggesting that at higher $\mathrm{pH}$ some additional $\mathrm{OH}^{-}$might enter the interlayer. Similar observations have also been reported for monosulfate (Matschei et al. 2007a) and Friedel's salt (Renaudin et al. 2015). This $\mathrm{OH}^{-}$uptake in I-AFm is further supported by TGA analyses, in which a clear difference in the mass loss curves between the $\mathrm{pH} \sim 12$ and $\mathrm{pH} \sim 13$ samples can be seen. Monoiodide synthesized at $\mathrm{pH} 13$ shows an additional water removal step at $\sim 150^{\circ} \mathrm{C}$ and $\sim 2 \mathrm{wt} . \%$ higher total mass loss.

The solubility product for monoiodide at $20^{\circ} \mathrm{C}$ was determined to be $-27.62 \pm 0.1$ for $\mathrm{pH} \sim 12$ and $-27.88 \pm 0.4$ for $\mathrm{pH} 13$ samples, respectively (Table 1). The equilibration time had no significant effect on the obtained solubility products, in agreement with the observation in a previous study focussing on sulfur- and selenium-containing AFm phases (Nedyalkova et al. 
2019). Based on the OH-incorporation observed by XRPD and TGA for the $\mathrm{pH} 13$ samples, the value of -27.62 at $\mathrm{pH} \sim 12$ was preferred for the monoiodide end member. This value is close to the solubility product of $-27.14 \pm 0.56$ (at $23^{\circ} \mathrm{C}$ ) published by Aimoz et al. (2012b).

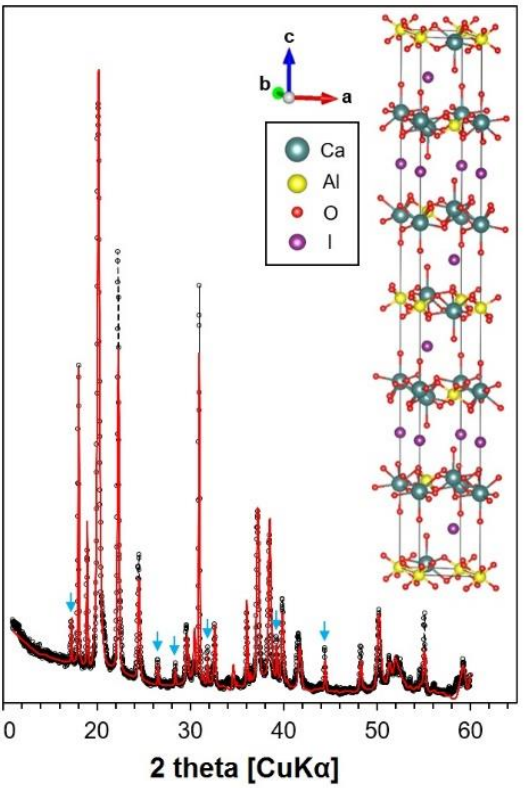

Figure 1: Experimental (black line) and calculated (red line) pattern of the I-AFm sample, synthesized at $\mathrm{pH} 13$, using the published structural model (Rapin et al. 1999) and a direct substitution placing $\mathrm{I}^{-}$on the 6-multiplicity site. The inset represents the corresponding crystal structure visualized with VESTA (Momma and Izumi 2008). Katoite peaks are marked with blue arrows.
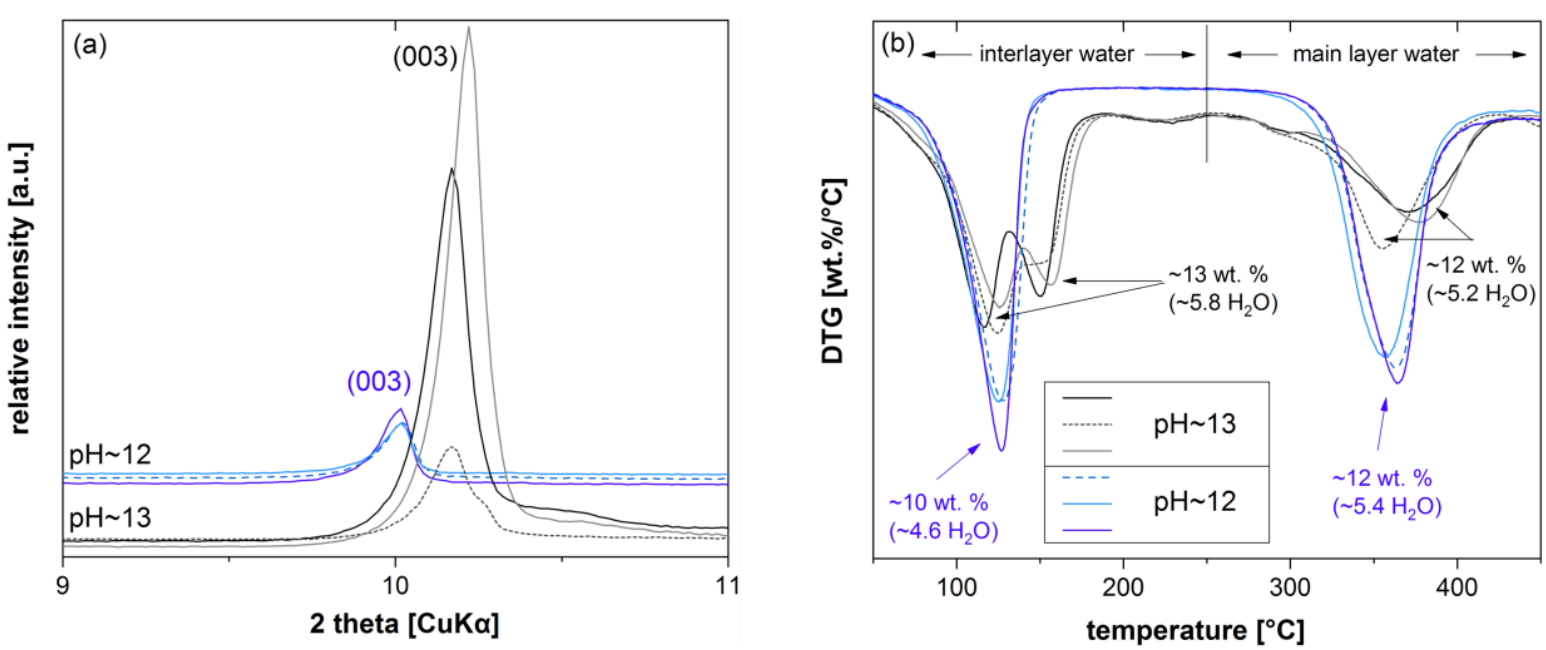

Figure 2: XRPD (a) and TGA (b) results for monoiodide samples showing the effect of $\mathrm{pH}$ ( $\mathrm{pH} \sim 12$ vs. $\mathrm{pH} \sim 13$ ). 


\subsubsection{Monocarbonate, hemicarbonate and hydroxy-AFm}

291

292

293

294

295

296

297

298

299

300

301

302

303

304

305

306

307

308

309

310

311

312

313

314

315

316

317

318

319

320

The monocarbonate samples show the formation of a single AFm phase with an interlayer distance of $7.55 \AA$ (Francois et al. 1998), containing only minor amounts of calcite $\left(\mathrm{CaCO}_{3}\right)$ as an impurity. The hydration state of the phase was confirmed to be $11 \mathrm{H}_{2} \mathrm{O}$ by TGA. For the $\mathrm{pH} \sim 12$ samples, a mean solubility product of $-29.53 \pm 1.2$ was calculated using the measured carbon concentrations in solution. Measured carbon values for the $\mathrm{pH} 13$ samples were close to the detection limit and the solubility products were calculated with estimated carbon concentrations assuming equilibrium with calcite, resulting in a mean $\log K$ of $-30.43 \pm 1.0$. The mean solubility product for all monocarbonate samples is thus $-30.19 \pm 0.8$ which is somewhat larger than most of the solubility products of -31.2 to -31.5 reported in literature (Damidot et al. 1994, Lothenbach and Winnefeld 2006, Matschei et al. 2007b), but overlap with these within the error. The difference between the solubility products obtained at $\mathrm{pH} \sim 12$ and $\mathrm{pH} \sim 13$ could indicate that calculated carbon concentrations underestimate the actual carbon concentration and thus the solubility of monocarbonate.

Hemicarbonate samples synthesized at $\mathrm{pH} \sim 13$ consist of hemicarbonate as the main phase coexisting with some carbonated hemicarbonate, visible by a reflection peak at about $11.4^{\circ} 2 \theta$ (Runčevski et al. 2012). At pH 12 in addition some monocarbonate was detected. The measured mass loss during TGA sums up to $12 \mathrm{H}_{2} \mathrm{O}$ as expected for hemicarbonate. The obtained $\log K$ of $-29.12 \pm 0.3$ is in good agreement with the values of -29.13 (Matschei et al. 2007b), 29.66 (Damidot et al. 1994) and -29.75 (Lothenbach and Winnefeld 2006) published before.

The low water hydrate OH-AFm13 with $d$-spacing of $7.99 \AA$ is observed in the hydroxy-AFm samples after drying, while in the solution the more hydrated $\mathrm{OH}-\mathrm{AFm} 19$ is present (Baquerizo et al. 2015). In addition, significant amounts of katoite and portlandite are observed; together they comprise up to about $80 \%$ of the solid in the samples which was confirmed by TGA. Their presence shows that $\mathrm{OH}-\mathrm{AFm}$ has already substantially decomposed to the thermodynamically more stable katoite and portlandite as reported previously (Matschei et al. 2007b). In fact, the calculated solubility product for the $\mathrm{OH}-\mathrm{AFm} 19$ is with $-26.36 \pm 2.0$ approximately one $\log$ unit lower than previously published values: -25.45 for OH-AFm19 (Lothenbach et al. 2012) as well as -25.40 (Matschei et al. 2007b), -25.35 (Zhang 2000) and -25.00 (Lothenbach et al. 2012) for OH-AFm13 consistent with the observed destabilisation. For the construction of the Lippmann diagrams, the solubility product of -26.4 was used based on the experimental data. 
322 Table 1: Liquid phase analysis and calculated solubility products for the AFm end members monoiodide, hemicarbonate, monocarbonate and hydroxy-AFm. Solubility products for hemicarbonate and monocarbonate at $\mathrm{pH} \sim 13$ were calculated assuming an equilibrium with monocarbonate or calcite, respectively, and are given in italic.

\begin{tabular}{|c|c|c|c|c|c|c|c|c|c|}
\hline Sample & $\begin{array}{l}\text { Eq. Time } \\
\text { [d] }\end{array}$ & $\begin{array}{c}\mathrm{pH} \\
20^{\circ} \mathrm{C}\end{array}$ & $\begin{array}{c}\mathrm{Al} \\
{[\mathrm{mmol} / \mathrm{l}]}\end{array}$ & $\begin{array}{c}\mathrm{Ca} \\
{[\mathrm{mmol} / \mathrm{l}]}\end{array}$ & $\begin{array}{c}\mathrm{I} \\
{[\mathrm{mmol} / \mathrm{l}]}\end{array}$ & $\begin{array}{c}\mathrm{C} \\
{[\mathrm{mmol} / \mathrm{l}]}\end{array}$ & $\begin{array}{c}\mathrm{Na} \\
{[\mathrm{mmol} / \mathrm{l}]}\end{array}$ & $\begin{array}{c}\mathrm{OH} \\
{[\mathrm{mmol} / \mathrm{l}]}\end{array}$ & $\begin{array}{l}\log \mathrm{K} \\
20^{\circ} \mathrm{C} \\
\end{array}$ \\
\hline \multicolumn{10}{|c|}{ monoiodide } \\
\hline$\# 1$ & 30 & 13.0 & 0.362 & 2.72 & 103.3 & - & 218.9 & 80.80 & -27.38 \\
\hline$\# 2$ & 30 & 13.0 & 0.406 & 2.24 & 102.6 & - & 213.4 & 80.80 & -27.60 \\
\hline \#3 & 30 & 13.0 & 0.396 & 2.02 & 100.9 & - & 213.4 & 77.79 & -27.84 \\
\hline$\# 4$ & 90 & 13.0 & 0.036 & 3.22 & 74.54 & - & 206.4 & 99.63 & -29.15 \\
\hline$\# 5$ & 90 & 12.9 & 0.323 & 2.20 & 102.3 & - & 218.0 & 81.53 & -28.13 \\
\hline$\# 6$ & 90 & 13.0 & 0.152 & 3.18 & 94.17 & - & 219.9 & 84.97 & -27.96 \\
\hline \#7 & 90 & 13.0 & 0.284 & 2.00 & 87.78 & - & 219.1 & 81.44 & -28.22 \\
\hline$\# 8$ & 180 & 12.9 & 0.182 & 4.80 & 89.70 & - & 211.3 & 81.79 & -27.28 \\
\hline$\# 9$ & 180 & 12.9 & 0.274 & 3.87 & 84.12 & - & 201.1 & 78.67 & -27.38 \\
\hline$\# 10$ & 90 & 11.7 & 3.85 & 13.20 & 12.56 & - & 0.510 & 4.42 & -27.60 \\
\hline$\# 11$ & 90 & 11.6 & 2.76 & 14.13 & 24.19 & - & 0.491 & 3.46 & -27.70 \\
\hline$\# 12$ & 90 & 11.6 & 2.70 & 16.54 & 25.75 & - & 0.487 & 3.14 & -27.64 \\
\hline$\# 13$ & 90 & 11.6 & 1.26 & 21.52 & 40.75 & - & 0.413 & 3.33 & -27.53 \\
\hline
\end{tabular}

hemicarbonate

$\begin{array}{llllllllll}\# 1 & 30 & 13.2 & 0.342 & 1.92 & - & <.01 & 212.2 & 122.7 & -29.04 \\ \# 2 & 30 & 13.2 & 0.338 & 2.24 & - & <.01 & 211.5 & 127.4 & -28.87 \\ \# 3 & 30 & 13.2 & 0.351 & 2.18 & - & <.01 & 210.1 & 127.4 & -28.87 \\ \# 4 & 90 & 13.2 & 0.080 & 3.73 & - & <.01 & 203.9 & 147.0 & -28.97 \\ \# 5 & 90 & 13.1 & 0.163 & 3.91 & - & <.01 & 218.5 & 129.3 & -28.93 \\ \# 6 & 90 & 13.2 & 0.210 & 2.88 & - & <.01 & 204.1 & 137.2 & -28.85 \\ \# 7 & 180 & 13.1 & 0.299 & 3.19 & - & <.01 & 209.7 & 120.7 & -28.83 \\ \# 8 & 180 & 13.0 & 0.238 & 3.67 & - & <.01 & 158.6 & 99.35 & -28.92 \\ & & & & & & & & & \\ \# 9 & 90 & 12.6 & 0.003 & 18.46 & - & 0.079 & 0.425 & 37.68 & -30.28 \\ \# 10 & 90 & 12.7 & 0.004 & 19.99 & - & 0.061 & 0.496 & 44.44 & -29.68 \\ \# 11 & 90 & 12.7 & 0.010 & 20.14 & - & 0.042 & 0.499 & 38.69 & -29.10\end{array}$

monocarbonate

$\begin{array}{lccccccccc}\# 1 & 30 & 13.1 & 6.05 & 0.082 & - & <.01 & 203.0 & 113.7 & -31.93 \\ \# 2 & 30 & 13.1 & 5.77 & 0.226 & - & <.01 & 215.3 & 113.7 & -30.63 \\ \# 3 & 30 & 13.1 & 7.70 & 0.160 & - & <.01 & 202.8 & 118.1 & -30.49 \\ \# 4 & 90 & 13.2 & 13.03 & 0.975 & - & <.01 & 208.3 & 136.0 & -27.84 \\ \# 5 & 90 & 13.1 & 3.40 & 0.529 & - & <.01 & 212.1 & 124.4 & -30.15 \\ \# 6 & 90 & 13.1 & 4.74 & 0.329 & - & <.01 & 210.2 & 124.3 & -30.48 \\ \# 7 & 180 & 13.1 & 4.00 & 0.168 & - & <.01 & 207.8 & 116.1 & -31.51 \\ \# 8 & 180 & 13.1 & 2.39 & 0.532 & - & <.01 & 207.8 & 116.1 & -30.44\end{array}$




\begin{tabular}{lrrrrrrrrr}
$\# 9$ & 90 & 11.9 & 3.57 & 3.92 & - & 0.075 & 0.439 & 7.65 & -29.35 \\
$\# 10$ & 90 & 11.8 & 2.58 & 3.95 & - & 0.107 & 0.501 & 5.69 & -30.06 \\
$\# 11$ & 90 & 11.9 & 3.95 & 5.33 & - & 0.035 & 0.521 & 7.26 & -29.17 \\
\multicolumn{2}{l}{ hydroxy-AFm } & & & & & & & & \\
$\# 1$ & 90 & 13.2 & 0.343 & 1.85 & - & - & 208.5 & 120.3 & -26.20 \\
$\# 2$ & 90 & 13.2 & 0.324 & 1.58 & - & - & 209.6 & 125.0 & -26.52 \\
\hline
\end{tabular}

*solubility products refer to a solid with $4 \mathrm{Ca}$ in the main layer: $K_{\mathrm{s} 0}=\left\{\mathrm{Ca}^{2+}\right\}^{4}\left\{\mathrm{AlO}_{2}^{-}\right\}^{2}\left\{\mathrm{X}^{-}\right\}^{2}\left\{\mathrm{OH}^{-}\right\}^{4}$ $\left\{\mathrm{H}_{2} \mathrm{O}\right\}^{x}$.

\subsection{AFm solid solution series}

Solid solution series between monoiodide-hydroxy-AFm, monoiodide-hemicarbonate and monoiodide-monocarbonate were examined at two different $\mathrm{pH}$ values of $\sim 12$ and $\sim 13$. The $\mathrm{pH}$ was found to have a minor effect on the observed solubility products as discussed in the previous section. Thus, the focus is on the $\mathrm{pH} \sim 12$ samples as monoiodide synthesized at $\mathrm{pH} \sim 13$ contained additional $\mathrm{OH}^{-}$, which would complicate the analyses of the solid solution. Moreover, measured carbon concentrations in the equilibrium solution of the $\mathrm{pH} \sim 13$ samples were close to the detection limit and therefore less reliable for the construction of the Lippmann diagrams. The data for the $\mathrm{pH} \sim 13$ samples can be found in the supplementary materials.

\subsubsection{Monoiodide-hydroxy-AFm}

A series of mixed monoiodide-hydroxy-AFm samples with different monoiodide mole fractions $\left(x_{\mathrm{I}}\right)$ were prepared. The XRPD data of the samples show the formation of one main AFm-like phase, in which a decreasing $x_{\mathrm{I}}$ is reflected by a gradual decrease of the interlayer distance from $8.8 \AA$ at $x_{\mathrm{I}}=0.93$ (corresponding to the I-AFm end member) down to $8.4 \AA$ at a total iodide fraction of $0.13\left(x_{\mathrm{I}}=0.13\right)$ (Fig. 3a). At this composition a second phase with a $d$-value of 7.9 $\AA$ appears, corresponding to OH-AFm13 (Fischer and Kuzel 1982). The evolution of the basal reflexion suggests the formation of a solid solution in which an increasing substitution of the larger $\mathrm{I}^{-}$anion $\left(2.10 \AA\right.$ ) by the smaller $\mathrm{OH}^{-}$anion (1.33 $\AA$ (Jenkins and Thakur 1979)) takes place in the AFm interlayer as the amount of iodide decreases. At very low $\mathrm{I}^{-}$contents two AFm phases coexist - a mixed (I,OH)-AFm and an OH-AFm, indicating the presence of a miscibility gap between $0 \leq x_{\mathrm{I}} \leq 0.2$.

FTIR analyses confirm the presence of one type of AFm phase in the samples with $x_{\mathrm{I}}=0.93$ 0.25. The intensities of the absorption bands show a systematic trend with changing composition (Fig. 3b). In the trigonal structure of the I-AFm end member with a R-3H space group 
(Rapin et al. 1999), a prominent absorption band at $\sim 775 \mathrm{~cm}^{-1}$ is observed which could be attributed to the Al-O deformation vibration. As composition changes towards smaller $x_{\mathrm{I}}$ values, the band is gradually weakened. The hydrogen bond network, seen in the frequency range between $\sim 3000$ and $\sim 3700 \mathrm{~cm}^{-1}$, also changes as a function of $x_{\mathrm{I}}$. The monoiodide end member is characterized by a strong absorption band at $\sim 3450 \mathrm{~cm}^{-1}$ with a shoulder at $\sim 3506 \mathrm{~cm}^{-1}$ caused by the stretching vibration of the interlayer water $\left(v\left(\mathrm{H}_{2} \mathrm{O}\right)\right)$ as well as an absorption band at $\sim 3624 \mathrm{~cm}^{-1}$ with a shoulder at $\sim 3600 \mathrm{~cm}^{-1}$ associated with $\mathrm{OH}$ stretching of the main layer water $(v(\mathrm{OH}))$. With the decrease of $x_{\mathrm{I}}$ the absorption bands become weaker and less resolved until at $x_{\mathrm{I}}=0.13$ an interruption of the trend is observed: $v\left(\mathrm{H}_{2} \mathrm{O}\right)$ is visible only as a very weak unresolved band between $\sim 3380$ and $\sim 3550 \mathrm{~cm}^{-1}$ and $v(\mathrm{OH})$ appears as a sharp peak shifted to the left at $\sim 3643 \mathrm{~cm}^{-1}$. This could indicate the limit of the solid solution and the formation of the $\mathrm{OH}-\mathrm{AFm}$ end member, since the spectra of the sample with $x_{\mathrm{I}}=0.13$ closely resembles the spectra of the sample with $x_{\mathrm{I}}=0$. In few of the samples, an absorption band at $\sim 1390 \mathrm{~cm}^{-1}$ is also observed suggesting some $\mathrm{CO}_{2}$ contamination.

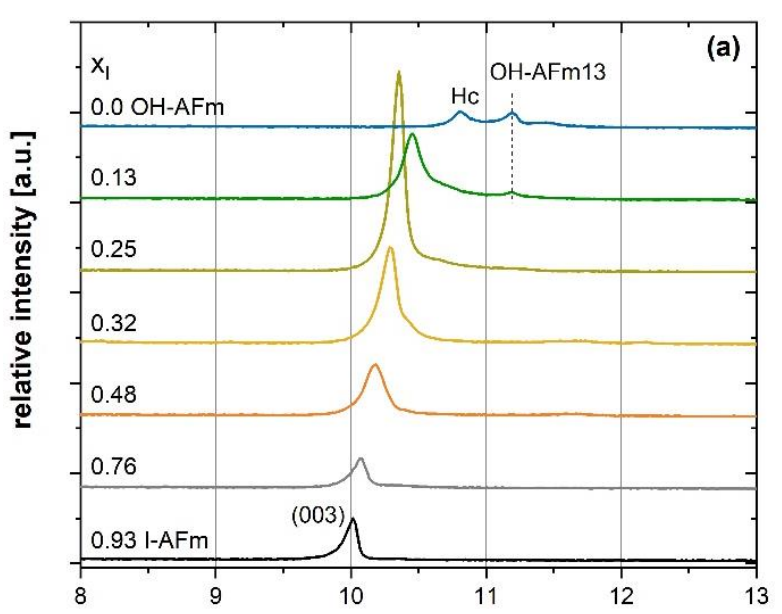

2 theta $[\mathrm{CuK} \alpha]$

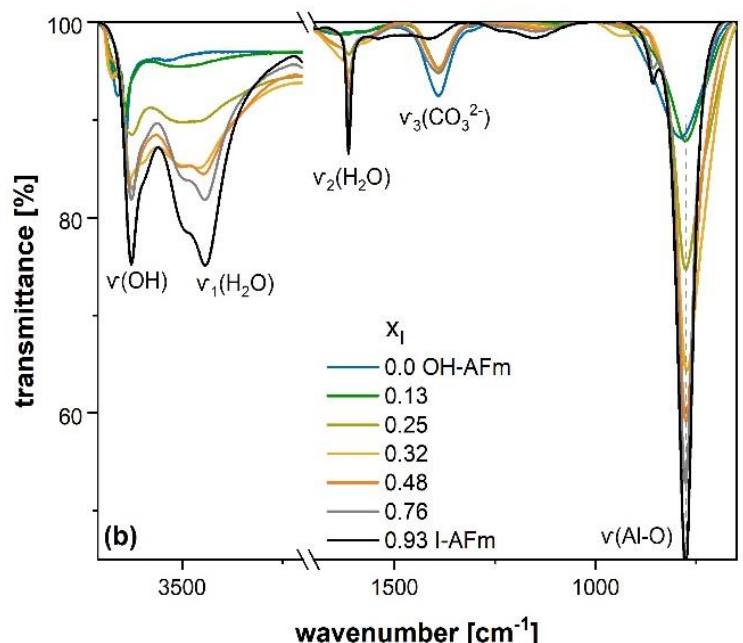

Figure 3: (a) XRD powder pattern of the samples belonging to the monoiodide-hydroxy-AFm solid solution series showing the low $2 \theta$ region and the shift in the basal reflexion. (b) FTIR spectra for the same samples.

For the monoiodide-OH-AFm solid solution series a Lippmann diagram was constructed (not shown due to the large uncertainties at low $x_{I}$ ) applying a 1:1 exchange model (with end members $\mathrm{Ca}_{2} \mathrm{AlI}(\mathrm{OH})_{6} \cdot 4.5 \mathrm{H}_{2} \mathrm{O}$ and $\left.\mathrm{Ca}_{2} \mathrm{Al}(\mathrm{OH})_{6.5} \cdot 6.25 \mathrm{H}_{2} \mathrm{O}\right)$ since both, iodide and hydroxyl are singly charged anions. In agreement with the miscibility gap observed by XRPD, an ideal solid 
solution model could not reproduce the experimental data points. Therefore the model was fitted by the Guggenheim parameters $a_{0}=-9.1$ and $a_{1}=6.4$, obtained on the basis of the experimentally observed miscibility gap at low $\mathrm{I}^{-}$concentrations and a best fit of the solidus data. The boundaries of the miscibility gap were thus determined to be $0.05 \leq x_{\mathrm{I}} \leq 0.21$.

\subsubsection{Monoiodide-hemicarbonate}

XRPD data of the samples with $x_{I}=0.93-0.39$ show the formation of a single AFm phase with only minor impurities of katoite and carbonated hemicarbonate. For the samples with $x_{\mathrm{I}}=0.16$ and $x_{\mathrm{I}}=0$ additional monocarbonate is also observed. The two samples with $x_{\mathrm{I}}=0.93$ and $x_{\mathrm{I}}=$ 0.90 contain an AFm phase with an interlayer distance of $8.8 \AA$ corresponding to the monoiodide end member (Rapin et al. 1999). With the decrease of the monoiodide mole fraction $\left(x_{\mathrm{I}}<\right.$ 0.9) the basal reflexion of the AFm starts to gradually shift from the monoiodide end member towards the hemicarbonate end member (Fig. 4a). The interlayer distance decreases systematically from $8.8 \AA$ at $x_{\mathrm{I}}=0.93$ to $8.2 \AA$ at $x_{\mathrm{I}}=0$ indicating the presence of a continuous solid solution between the two end members.

FTIR analyses confirm the solid solution formation in the samples. The samples with $x_{\mathrm{I}}=0.93$ and $x_{\mathrm{I}}=0.9$ show identical spectra consistent with the spectra expected for monoiodide. The intensities of the absorption bands show systematic trend with changing composition between $x_{\mathrm{I}}=0.9-0$ (Fig. 4b). As the AFm composition changes towards smaller $x_{\mathrm{I}}$ values, the Al-O absorption band at $\sim 775 \mathrm{~cm}^{-1}$ in monoiodide is gradually weakened and shifts continuously towards $\sim 740 \mathrm{~cm}^{-1}$, corresponding to the region in which it is found in the hemicarbonate end member. This shift could be attributed to the different environment $\mathrm{Al}$ encounters in the samples with decreasing $x_{\mathrm{I}}$. Although both end members have a trigonal structure, their crystal symmetry differs and is described in the R-3H space group for I-AFm (Rapin et al. 1999) and R-3cH for hemicarbonate (Runčevski et al. 2012). The amount of $\mathrm{CO}_{3}{ }^{2-}$ addition is reflected by the absorption band at $\sim 1390 \mathrm{~cm}^{-1}$ caused by the asymmetric stretching mode of the $\mathrm{CO}_{3}{ }^{2-}$ group $\left(\mathrm{v}_{3^{-}}\right.$ $\left.\mathrm{CO}_{3}{ }^{2-}\right)$ in the hemicarbonate-containing samples $\left(x_{\mathrm{I}}=0.9-0\right)$. 

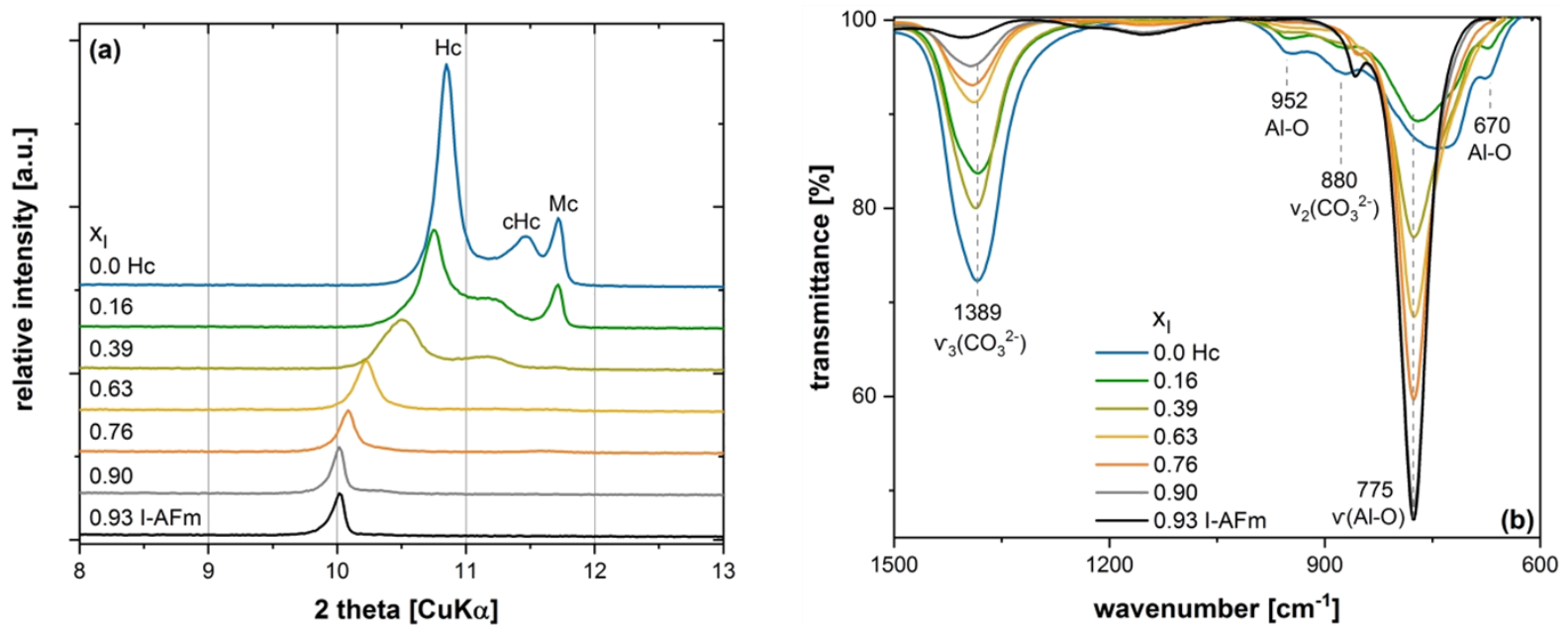

410

Figure 4: (a) XRD powder pattern of the samples belonging to the monoiodide-hemicarbonate solid solution series showing the evolution of the basal reflexion with changing composition; (b) FTIR analyses for the same samples showing the changes in the $\mathrm{v}_{3}\left(\mathrm{CO}_{3}{ }^{2-}\right)$ and $\mathrm{v}(\mathrm{Al}-\mathrm{O})$ absorption bands as a function of the monoiodide mole fraction $x_{\mathrm{I}}$.

As monoiodide and hemicarbonate show different space groups, iodide could be present either in separate interlayers (interstratification) leading to alternating stacking of the layers, as suggested previously in literature (Aimoz et al. 2012a), or alternatively iodide could replace hydroxide/carbonate in hemicarbonate within the same layer. In order to resolve the structure of the observed mixed monoiodide-hemicarbonate AFm phase, Rietveld refinement was conducted on the experimental XRPD data, considering an interstratification of the two end members that gives rise to an AFm with an alternating interlayer stacking of hemicarbonate with IAFm as proposed by Aimoz et al. (2012a). Assuming such an alternating-layered AFm configuration and a relative $\mathrm{I}^{-}$dosage of $50 \%$ and regular stacking, a structural model was built and its diffraction pattern calculated (Fig. 5a). When refining the experimental data of the sample with nominal $\mathrm{I}^{-}$dosage of $x_{\mathrm{I}}=0.5$ (refined $x_{\mathrm{I}}=0.63$ ) with the constructed configuration, however, a clear mismatch of the calculated with the measured pattern was noted; strong (003) and (009) peaks were predicted but not observed experimentally (Fig. 5b). Similarly, also (004), (005), (007) and (008) diffraction bands were predicted by the calculation, but not observed in the experimental data. In the R-3cH symmetry of the hemicarbonate structure (Runčevski et al. 2012) the latter peaks are absent. In the alternating-layer model, since the $I^{-}$-enriched interlayer is thicker than the $\mathrm{OH}^{-} / \mathrm{CO}_{3}{ }^{2-}$-enriched interlayer, such symmetry no longer exists and the above-mentioned diffractions are allowed. In the experimental XRPD of all monoiodide-hemicarbonate solid solution samples, these peaks remain absent despite the I-dosage, indicating 
that the original symmetry of hemicarbonate is conserved during I-uptake. Based on these observations, the alternating-layered model fails to decribe the I-substituted AFm synthesized in this study. It should be noted, however, that stacking disorders could be another reason for the observed discrepancies in the diffraction patterns and that further investigations are needed to confirm the structure of the mixed monoiodide-hemicarbonate AFm samples.

(a)

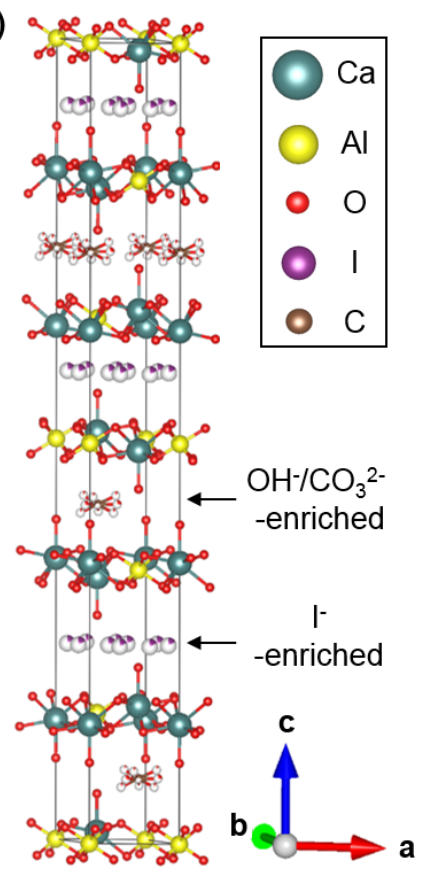

(b)

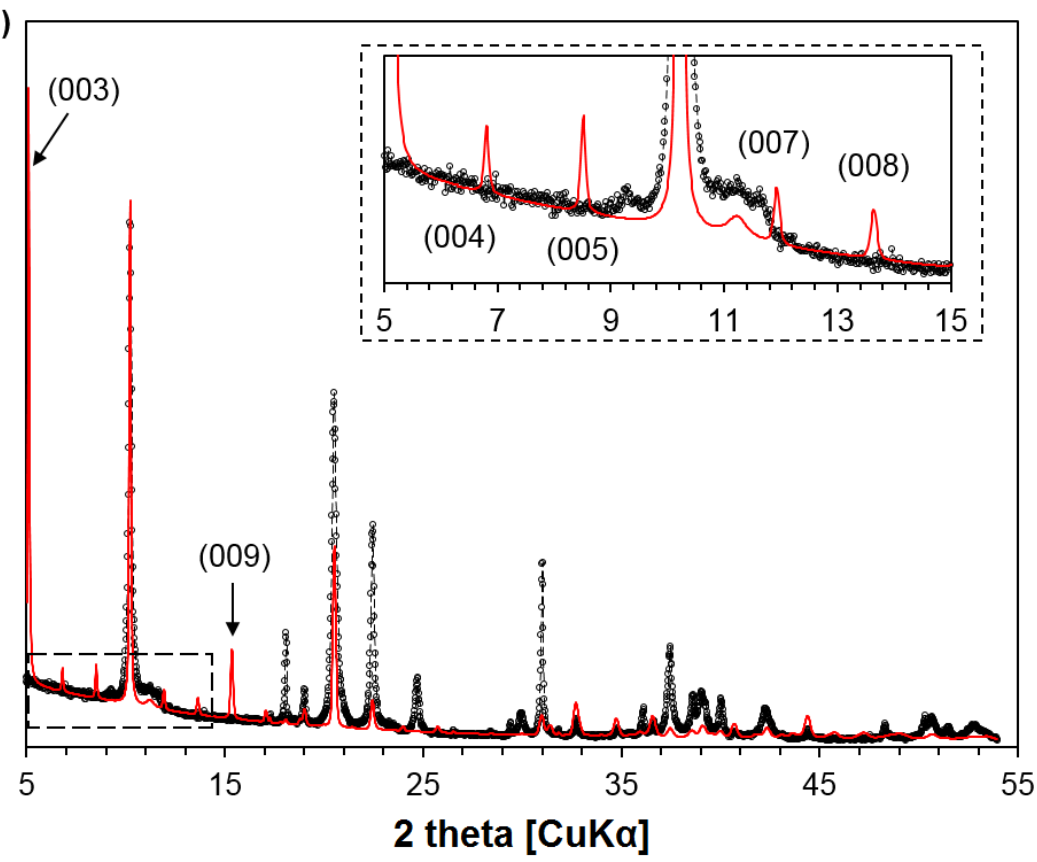

Figure 5: (a) Crystal structure of an alternating-layered AFm phase with $x_{\mathrm{I}}=0.5$ and regular stacking of the $\mathrm{I}^{-}$-enriched and $\mathrm{OH}^{-} / \mathrm{CO}_{3}{ }^{2-}$-enriched interlayer regions. (b) Experimental (black line) and calculated (red line) XRPD patterns for a sample with monoiodide mole fraction $x_{\mathrm{I}}=$ 0.63 . The dashed square inset shows a magnification of the $2 \theta$ range between $5^{\circ}$ and $15^{\circ}$.

To explore the possibility of an interlayer containing simultaneously $\mathrm{I}^{-}$and $\mathrm{OH}^{-} / \mathrm{CO}_{3}{ }^{2-}$, the occupancy of $\mathrm{I}^{-}$(i.e. the probability that the interlayer anion site is occupied by $\mathrm{I}^{-}$) was fitted based on the XRPD data. The fitted $\mathrm{I}^{-}$occupancy (refined monoiodide mole fraction) as a function of the nominal monoiodide mole fraction is plotted in Figure 6a, where a continuous increasing of $\mathrm{I}^{-}$uptake is evidenced. The fitted lattice parameter $a$ and $c$ are plotted in Figure $6 \mathrm{~b}$ and $6 \mathrm{c}$, respectively. The lattice parameter $a$ shows some fluctuations, but it generally increases with increasing $x_{\mathrm{I}}$. The overall variance is only $\sim 0.2 \AA$, which is smaller than $0.4 \%$ of the lattice parameter $a$. On the contrary, the lattice parameter $c$ clearly follows an increasing trend with an increase in $x_{\mathrm{I}}$, i.e. from $\sim 49 \AA$ at $x_{\mathrm{I}}=0$ to $\sim 53 \AA$ at $x_{\mathrm{I}}=0.9$ and $x_{\mathrm{I}}=0.93$. All these observations 
indicate that the $\mathrm{I}^{-}$uptake into the AFm structure is a continuous process between $x_{\mathrm{I}}=0$ and $x_{\mathrm{I}}$ $=0.9$. The uptake seems to happen by homogeneous substitution of $\mathrm{OH}^{-} / \mathrm{CO}_{3}{ }^{2-}$ by $\mathrm{I}^{-}$resulting in an interlayer simultaneously containing $\mathrm{I}^{-}$and $\mathrm{OH}^{-} / \mathrm{CO}_{3}{ }^{2-}$ anions.
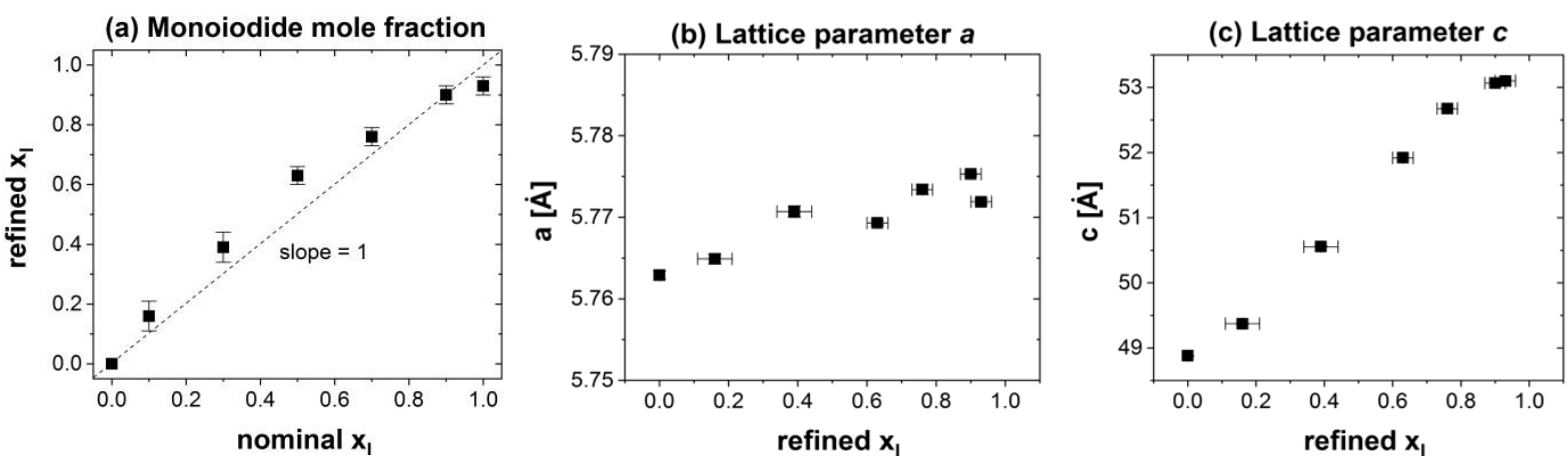

Figure 6: Refinement results showing the amount of $\mathrm{I}^{-}$incorporated in the structure (a) and the lattice parameters $a$ (b) and $c$ (c). The dashed line in (a) represents the slope of 1 .

The results of the chemical analyses of the equilibrium solution as well as the observations made by XRPD, TGA and FTIR were used for the construction of a Lippmann diagram. XRPD data suggest the formation of a continuous solid solution between the two end members, which is also confirmed by the modelling of the solubility data. The end members were defined according to the Vanselow convention (Vanselow 1932), also applied by Aimoz et al. (2012b) to describe the solid solution formation between monoiodide and monosulfate. An ideal solid solution model did not fully reproduce the experimental solidus data, which lay slightly below the modelled solidus curve (Fig. 7). A regular solid solution model with an interaction parameter $a_{0}$ was introduced to fit the solidus data. An acceptable fit was obtained with $a_{0}=-1.2$. Experimental solutus data are in a good agreement with the modelled solutus curve.

西
1 42 
483

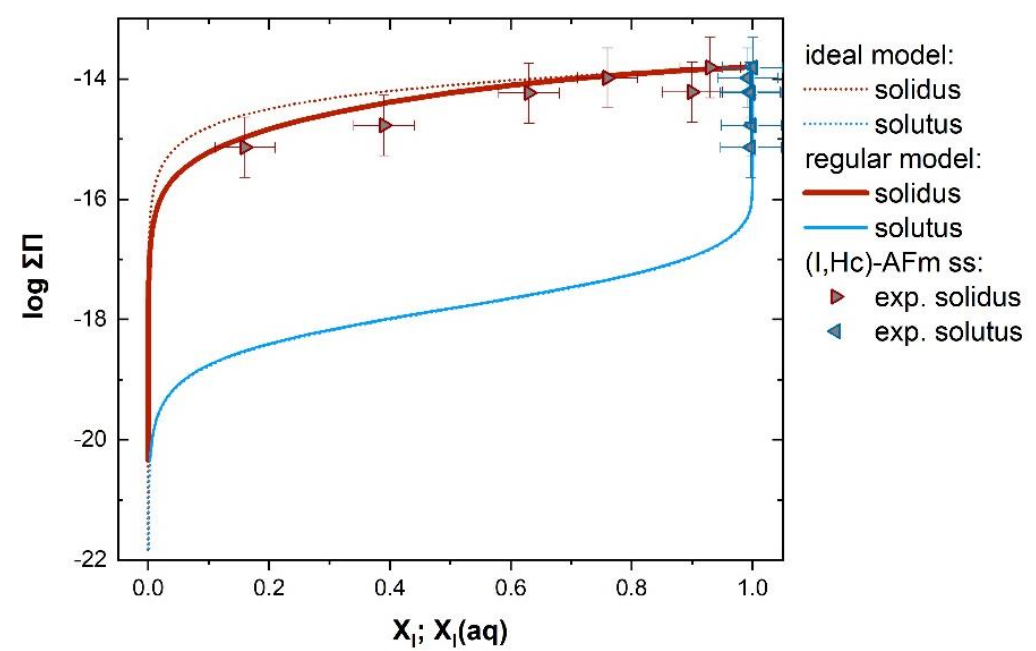

Figure 7: Lippmann diagram for the monoiodide-hemicarbonate solid solution series at $20^{\circ} \mathrm{C}$ using an ideal-solid solution model (dotted lines) and a solid solution model with the Guggenheim parameter $a_{0}=-1.2$ (solid lines).

\subsubsection{Monoiodide-monocarbonate}

XRPD data indicate an incomplete miscibility between the two phases in the case of the monoiodide-monocarbonate solid solution series. Samples, synthesized at $\mathrm{pH} \sim 12$, with composition $0.65 \leq x_{\mathrm{I}} \leq 1.0$ consist of one main AFm phase with minor katoite and portlandite impurities. In samples with $x_{\mathrm{I}} \leq 0.44$ additional monocarbonate (accompanied with minor calcite impurities) appears, indicating the presence of a miscibility gap (Fig. 8a). In the composition range $0.09 \leq x_{\mathrm{I}} \leq 0.94$, the basal peak between 10 to $11^{\circ} 2 \theta$ shifts from the monoiodide end member towards lower $\mathrm{d}$ values (and thus higher $2 \theta$ values), consistent with a progressive exchange of the relatively large $\mathrm{I}^{-}$anion. It is interesting to note that the position of this basal peak corresponds to the basal spacing observed for the monoiodide-hemicarbonate series.

The observations made in XRPD were confirmed by FTIR analyses. The formation of a trigonal AFm phase in the samples with composition $0.09 \leq x_{\mathrm{I}} \leq 0.9$ is indicated by the position of the Al-O absorption band (Fig. 8b). At composition $x_{\mathrm{I}}=0.44$ additional absorption bands at $\sim 952$ $\mathrm{cm}^{-1}, \sim 880 \mathrm{~cm}^{-1}, \sim 817 \mathrm{~cm}^{-1}, \sim 720 \mathrm{~cm}^{-1}$ and $\sim 670 \mathrm{~cm}^{-1}$ appear indicating the presence of a triclinic monocarbonate as a second phase (Dilnesa et al. 2011). Due to the triclinic structure of monocarbonate, also the $v_{3}\left(\mathrm{CO}_{3}{ }^{2-}\right)$ band is split into two components with absorption at $\sim 1362$ $\mathrm{cm}^{-1}$ and $\sim 1415 \mathrm{~cm}^{-1}$ (Fischer and Kuzel 1982), making the phase easily distinguishable from hemicarbonate in FTIR. The band splitting is observed here only for the $x_{\mathrm{I}}=0$ sample. However, the broad absorption $v_{3}\left(\mathrm{CO}_{3}{ }^{2-}\right)$ peaks for the $x_{\mathrm{I}}=0.09$ and $x_{\mathrm{I}}=0.44$ samples, would suggest two overlapping signals at $\sim 1362 \mathrm{~cm}^{-1}$ and $\sim 1415 \mathrm{~cm}^{-1}$ rather than one absorption band at $\sim 1389 \mathrm{~cm}^{-}$ 
1. The splitting of the $v_{3}\left(\mathrm{CO}_{3}{ }^{2-}\right)$ absorption band with the appearance of monocarbonate in the

510 samples is also visible in the monoiodide-monocarbonate series synthesized at $\mathrm{pH} 13$ (Fig.

511 A2d).

512

The miscibility gap could be related to the difference in the structure of the two end members (trigonal (I-AFm) vs. triclinic (monocarbonate)), and to the planar arrangement of carbonate in the $\mathrm{CO}_{3}$-AFm interlayer which prevents the uptake of the larger $\mathrm{I}^{-}$anion into the structure. $\mathrm{A}$ comparable behaviour has been observed for chloride uptake in monocarbonate, where an incomplete solid solution exists between the Cl-AFm end member (Friedel's salt (Terzis et al. 1987)) and monocarbonate with a miscibility gap at low $\mathrm{Cl}$ concentrations (e.g. Balonis et al. 2010, Mesbah et al. 2011b).

519

520
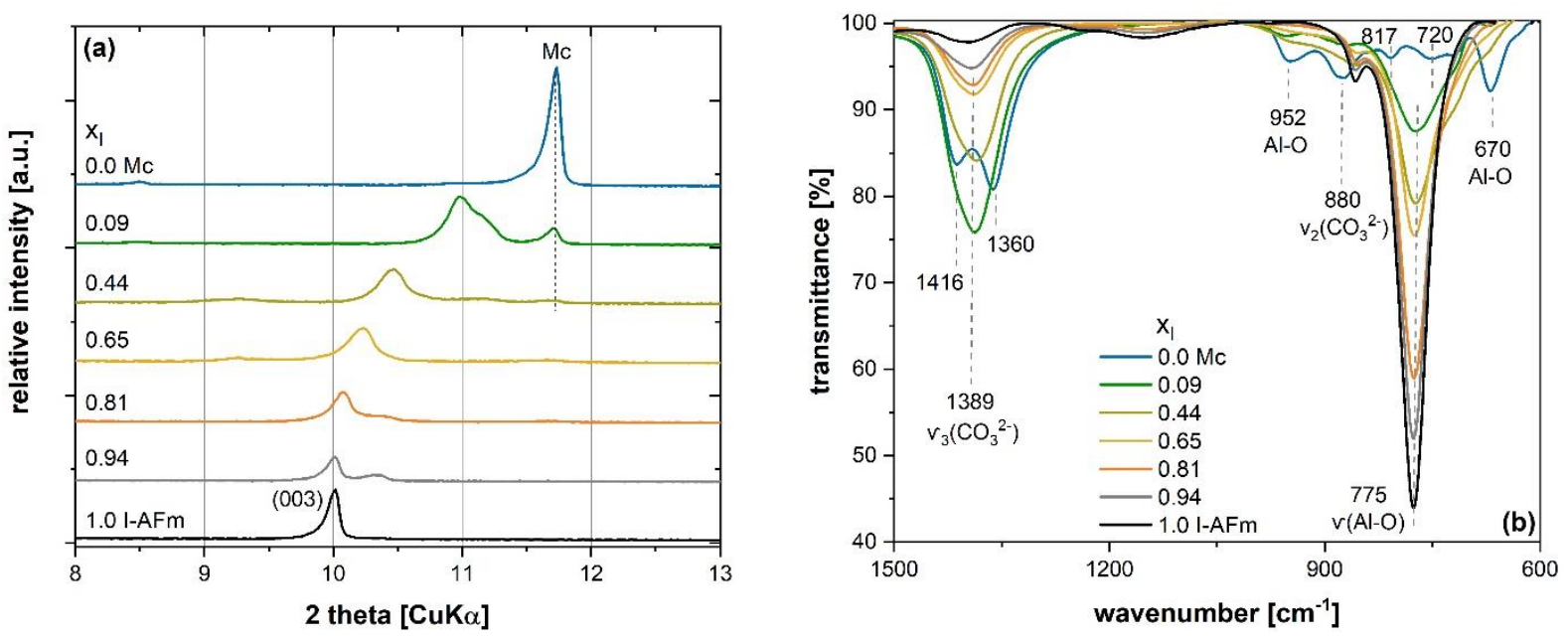

Figure 8: (a) XRD powder pattern of the samples belonging to the monoiodide-monocarbonate solid solution series showing a miscibility gap at $x_{\mathrm{I}} \leq 0.44$. (b) FTIR spectra of the same samples confirming the coexistence of a mixed trigonal AFm phase and monocarbonate.

A Lippmann diagram for the monoiodide-monocarbonate solid solution series was constructed applying the solid solution model for monoiodide-hemicarbonate (Fig. 9) (see section 3.3 for discussion). The experimental data has been plotted alongside with the data from the monoiodide-hemicarbonate solid solution series for comparison. The model shows a good fit for the experimental solutus data. Experimental solidus data is well reproduced by the curve of the regular model with the Guggenheim parameter $a_{0}=-1.2$ (solid line in Fig. 9) and shows similar values to the ones obtained for the monoiodide-hemicarbonate series. At $x_{I}<0.5$, a displace- 
results from the monoiodide-hemicarbonate experimental series can be observed. This could be explained by the fact that with increasing carbonate concentration monocarbonate is being stabilized relative to the (moniodide-hemicarbonate)-AFm phase as also seen by XRPD.

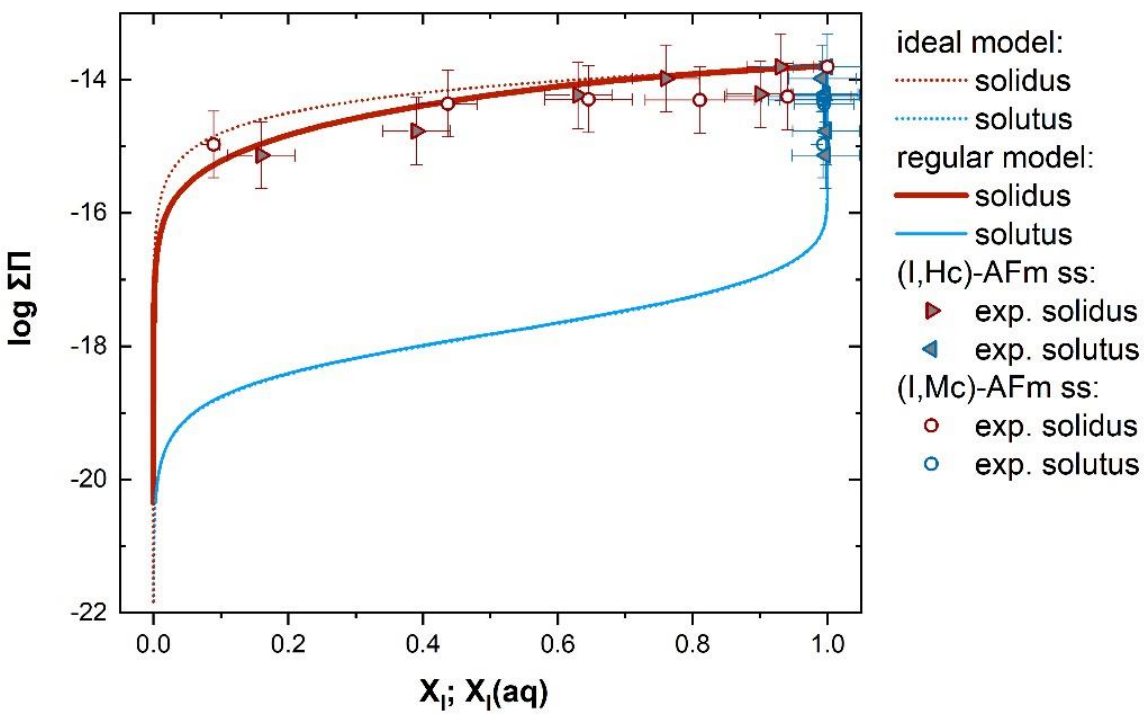

Figure 9: Lippmann diagram for the monoiodide-monocarbonate (circles) solid solution series plotted together with experimental data from the monoiodide-hemicarbonate (triangles) series for comparison. The Lippmann diagram was calculated at $20^{\circ} \mathrm{C}$ using the ideal (dotted lines) and regular (solid lines) solution model with the Guggenheim parameter $a_{0}=-1.2$ for monoiodide-hemicarbonate.

\subsection{Discussion}

The addition of $\mathrm{I}^{-}$to the $\mathrm{CaO}-\mathrm{Al}_{2} \mathrm{O}_{3}-\left(\mathrm{CO}_{2}\right)-\mathrm{H}_{2} \mathrm{O}$ system leads to the formation of solid solutions (complete or incomplete with a miscibility gap) between the different end members. Monoiodide readily incorporates $\mathrm{OH}^{-}$at high $\mathrm{pH}$ and a mixed (I,OH)-AFm seems to be the stable phase at $\mathrm{pH} \sim 13$ and high $\mathrm{I}^{-}$concentration. At compositions close to the $\mathrm{OH}-\mathrm{AFm}$ end member, a miscibility gap between monoiodide and $\mathrm{OH}-\mathrm{AFm}$ exists, which could be explained with the difference in the ionic size between $\mathrm{I}^{-}(2.10 \AA)$ and $\mathrm{OH}^{-}(1.33 \AA$ (Jenkins and Thakur 1979)). The much larger $\mathrm{I}^{-}$anion cannot easily substitute for the small $\mathrm{OH}^{-}$in the $\mathrm{OH}-\mathrm{AFm}$ lattice.

Small amounts of carbonate are also well incorporated in the AFm structure together with $\mathrm{I}^{-}$ and $\mathrm{OH}^{-}$, resulting in the precipitation of a mixed monoiodide-hemicarbonate AFm. Higher carbonate concentration, on the other hand, stabilize monocarbonate as previously reported by 
Aimoz et al. (2012a). In a comparison between the monoiodide-hemicarbonate and monoiodide-monocarbonate solid solution series (Fig. 10), similar $d$-values are observed, thus suggesting that in both cases the same mixed AFm phase is formed. In the presence of small amounts of carbonate, solid solution formation is promoted and a mixed ( $\left.\mathrm{I}, \mathrm{OH}, \mathrm{CO}_{3}\right)-\mathrm{AFm}$ precipitates in each of the two series, favoured by the same trigonal crystal structure of monoiodide and hemicarbonate. With increasing carbonate concentration, monocarbonate is preferred as hemicarbonate is metastable relative to monocarbonate (Kuzel and Pöllmann 1991, Lothenbach et al. 2008) and both phases do not mix (Pöllmann 2006).
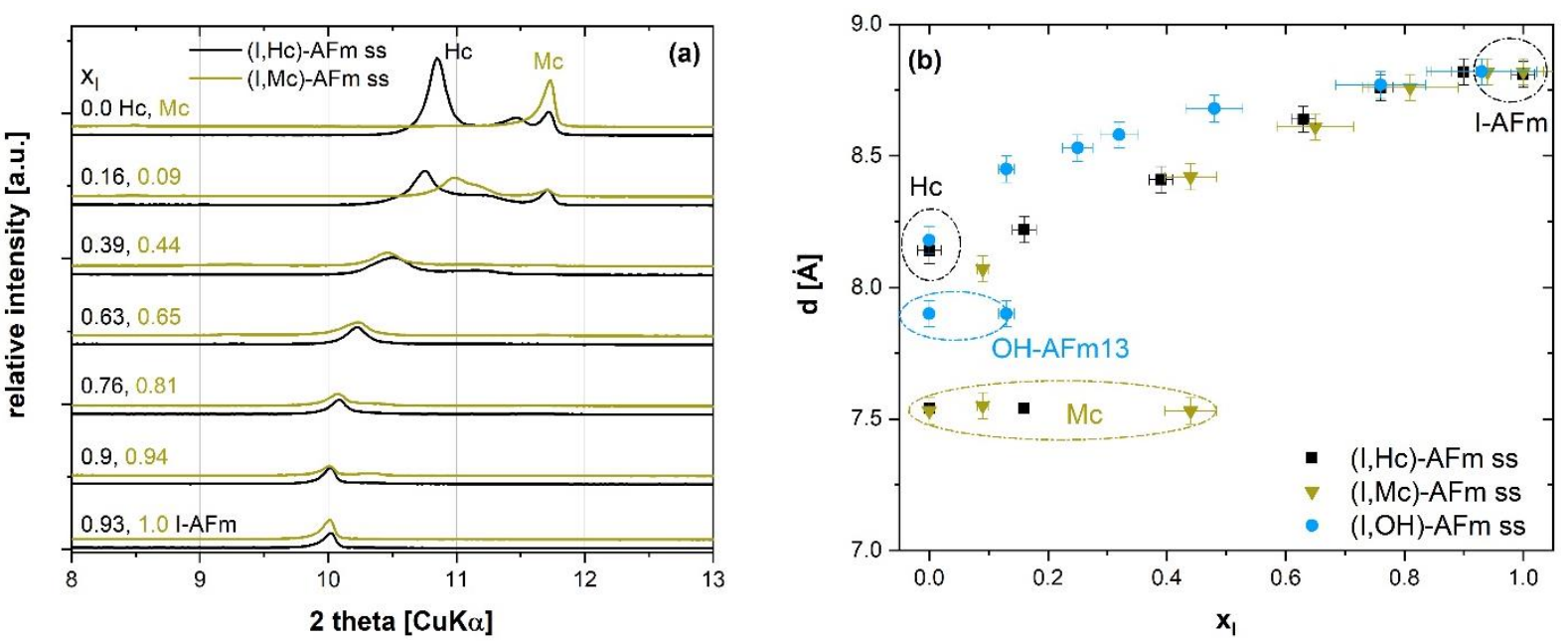

Figure 10: (a) Comparison between the X-ray diffraction patterns of the monoiodide-hemicarbonate (in black) and monoiodide-monocarbonate (in green) solid solution series synthesized at $\mathrm{pH}$ 12. (b) Evolution of the interlayer distance with changing mole fraction of the I-AFm end member $x_{\mathrm{I}}$ for the three studied solid solution series at $\mathrm{pH} \sim 12$. Hc: hemicarbonate; $\mathrm{OH}-$ AFm13: hydroxy-AFm with $13 \mathrm{H}_{2} \mathrm{O}$; I-AFm: monoiodide; Mc: monocarbonate; ss: solid solution.

\section{Conclusions}

Experimental data indicate the formation of extensive solid solutions between monoiodide and hydroxy-AFm and monoiodide and hemicarbonate. Whereas the solid solution between monoiodide and hemicarbonate is complete, the presence of a small miscibility gap with composition $0.05 \leq x_{\mathrm{I}} \leq 0.21$ was detected between monoiodide and hydroxy-AFm. Monocarbonate, on the other hand, does not mix with monoiodide and is the stable phase at high carbonate 
concentrations, coexisting with a mixed (monoiodide-hemicarbonate)-AFm phase. The solubility of the synthesized phases and their compositions have been visualized in terms of Lippmann diagrams.

In the presence of $\mathrm{OH}^{-}$and/or small amounts of $\mathrm{CO}_{3}{ }^{2-}$, iodide is readily incorporated in the $\mathrm{AFm}$ interlayers leading to the formation of solid solutions with hydroxy-AFm and hemicarbonate. Both phases, however, are metastable and transform to katoite and portlandite (hydroxy-AFm) or monocarbonate (hemicarbonate) with time. The latter AFm phase, however, is not capable of incorporating iodide. In regard to the safe disposal of iodine-129 in cement-based L/ILW repositories, the results of this study indicate that solid solution formation is an active mechanism over a wide concentration range and the formation of mixed, iodine-bearing AFm phases need to be considered in the modelling approach. The experimental data further implies that the presence of carbonate causes the formation of monocarbonate in the long term, reducing thus the capability of AFm phases to immobilize iodide.

\section{Acknowledgements}

The research leading to these results has received funding from the European Union's Horizon 2020 Research and Training Programme of the European Atomic Energy Community (EURATOM) (H2020-NFRP-2014/2015) under grant agreement $n^{\circ} 662147$ (CEBAMA). Prof. Guillaume Renaudin (Université Clermont Auvergne, France) is greatly acknowledged for the help with the XRPD analysis of monoiodide. The authors would also like to thank Luigi Brunetti (Empa) and Dr. Frank Winnefeld (Empa) for their assistance with the sample characterization measurements.

\section{References}

Aimoz, L., E. Wieland, C. Taviot-Guého, R. Dähn, M. Vespa and S. V. Churakov (2012a). "Structural insight into iodide uptake by AFm phases." Environmental Science \& Technology 46(7): 3874-3881, https://doi.org/10.1021/es204470e. Aimoz, L., D. A. Kulik, E. Wieland, E. Curti, B. Lothenbach and U. Mäder (2012b). "Thermodynamics of AFm- $\left(\mathrm{I}_{2}, \mathrm{SO}_{4}\right)$ solid solution and of its end-members in aqueous media." Applied Geochemistry 27(10): 2117-2129, https://doi.org/10.1016/j.apgeochem.2012.06.006. Aruja, E. (1961). "The unit cell and space group of $4 \mathrm{CaO} . \mathrm{Al}_{2} \mathrm{O}_{3} \cdot 19 \mathrm{H}_{2} \mathrm{O}$ polymorphs." Acta Crystallographica 14(12): 1213-1216, https://doi.org/10.1107/S0365110X61003557. 
Atkins, M. and F. Glasser (1992). "Application of Portland cement-based materials to radioactive waste immobilization." Waste Management 12(2-3): 105-131, https://doi.org/10.1016/0956-053X(92)90044-J.

Balonis, M., B. Lothenbach, G. Le Saout and F. P. Glasser (2010). "Impact of chloride on the mineralogy of hydrated Portland cement systems." Cement and Concrete Research 40(7): 10091022, https://doi.org/10.1016/j.cemconres.2010.03.002.

Baquerizo, L. G., T. Matschei, K. L. Scrivener, M. Saeidpour and L. Wadsö (2015). "Hydration states of AFm cement phases." Cement and Concrete Research 73: 143-157, https://doi.org/10.1016/j.cemconres.2015.02.011.

Brown, D. R. and M. W. Grutzeck (1985). "The synthesis and characterization of calcium aluminate monoiodide." Cement and Concrete Research 15(6): 1068-1078, https://doi.org/10.1016/0008-8846(85)90099-7.

Damidot, D., S. Stronach, A. Kindness, M. Atkins and F. Glasser (1994). "Thermodynamic investigation of the $\mathrm{CaO} . \mathrm{Al}_{2} \mathrm{O}_{3} \cdot \mathrm{CaCO}_{3} \cdot \mathrm{H}_{2} \mathrm{O}$ closed system at $25^{\circ} \mathrm{C}$ and the influence of $\mathrm{Na}_{2} \mathrm{O}$." Cement and Concrete Research 24(3): 563-572, https://doi.org/10.1016/00088846(94)90145-7.

Dilnesa, B., B. Lothenbach, G. Le Saout, G. Renaudin, A. Mesbah, Y. Filinchuk, A. Wichser and E. Wieland (2011). "Iron in carbonate containing AFm phases." Cement and Concrete Research 41(3): 311-323, https://doi.org/10.1016/j.cemconres.2010.11.017.

Evans, D. G. and R. C. Slade (2006). Structural aspects of layered double hydroxides. Layered double hydroxides, Springer: 1-87, https://doi.org/10.1007/430_005.

Fischer, R. and H.-J. Kuzel (1982). "Reinvestigation of the system $\mathrm{C}_{4} \mathrm{~A} . \mathrm{nH}_{2} \mathrm{O}-\mathrm{C}_{4} \mathrm{~A} . \mathrm{CO}_{2}$. $\mathrm{nH}_{2} \mathrm{O}$." Cement and Concrete Research 12(4): 517-526, https://doi.org/10.1016/00088846(82)90066-7.

Francois, M., G. Renaudin and O. Evrard (1998). "A cementitious compound with composition $3 \mathrm{CaO} . \mathrm{Al}_{2} \mathrm{O}_{3} \cdot \mathrm{CaCO}_{3} \cdot 11 \mathrm{H}_{2} \mathrm{O}$." Acta Crystallographica Section C 54(9): 1214-1217, https://doi.org/10.1107/S0108270198004223. Geng, G., R. N. Vasin, J. Li, M. J. A. Qomi, J. Yan, H.-R. Wenk and P. J. Monteiro (2018). "Preferred orientation of calcium aluminosilicate hydrate induced by confined compression." Cement and Concrete Research 113: 186-196, https://doi.org/10.1016/j.cemconres.2018.09.002.

Glasser, F., A. Kindness and S. Stronach (1999). "Stability and solubility relationships in AFm phases: Part I. Chloride, sulfate and hydroxide." Cement and Concrete Research 29(6): 861866, https://doi.org/10.1016/S0008-8846(99)00055-1.

Glynn, P. (2000). "Solid-solution solubilities and thermodynamics: sulfates, carbonates and halides." Reviews in Mineralogy and Geochemistry 40(1): 481-511, https://doi.org/10.2138/rmg.2000.40.10.

Jenkins, H. and K. Thakur (1979). "Reappraisal of thermochemical radii for complex ions." Journal of Chemical Education 56(9): 576, https://doi.org/10.1021/ed056p576.

Kulik, D. A., T. Wagner, S. V. Dmytrieva, G. Kosakowski, F. F. Hingerl, K. V. Chudnenko and U. R. Berner (2013). "GEM-Selektor geochemical modeling package: revised algorithm and GEMS3K numerical kernel for coupled simulation codes." Computational Geosciences 17(1): 1-24, https://doi.org/10.1007/s10596-012-9310-6.

Kuzel, H.-J. (1971). "Zur Frage der Mischkristallbildung von Calciumaluminiumhydroxysalzen." Neues Jahrb. Mineral.: 477-491.

Kuzel, H.-J. and H. Pöllmann (1991). "Hydration of $\mathrm{C}_{3} \mathrm{~A}$ in the presence of $\mathrm{Ca}(\mathrm{OH})_{2}, \mathrm{CaSO}_{4}$. $2 \mathrm{H}_{2} \mathrm{O}$ and $\mathrm{CaCO}_{3}$." Cement and Concrete Research 21(5): 885-895, https://doi.org/10.1016/0008-8846(91)90183-I. 
Lippmann, F. (1980). "Phase diagrams depicting the aqueous solubility of mineral systems." Neues Jahrb. Mineral. 139(1): 1-25.

Lothenbach, B., G. Le Saout, E. Gallucci and K. Scrivener (2008). "Influence of limestone on the hydration of Portland cements." Cement and Concrete Research 38(6): 848-860, https://doi.org/10.1016/j.cemconres.2008.01.002.

Lothenbach, B., L. Pelletier-Chaignat and F. Winnefeld (2012). "Stability in the system CaO$\mathrm{Al}_{2} \mathrm{O}_{3}-\mathrm{H}_{2} \mathrm{O}$." Cement and Concrete Research 42(12): 1621-1634, https://doi.org/10.1016/j.cemconres.2012.09.002.

Lothenbach, B. and F. Winnefeld (2006). "Thermodynamic modelling of the hydration of Portland cement." Cement and Concrete Research 36(2): 209-226, https://doi.org/10.1016/j.cemconres.2005.03.001.

Lutterotti, L., D. Chateigner, S. Ferrari and J. Ricote (2004). "Texture, residual stress and structural analysis of thin films using a combined X-ray analysis." Thin Solid Films 450(1): 3441, https://doi.org/10.1016/j.tsf.2003.10.150.

Lutterotti, L., S. Matthies and H. Wenk (1999). "MAUD: a friendly Java program for material analysis using diffraction." IUCr: Newsletter of the CPD 21(14-15).

Matschei, T., B. Lothenbach and F. Glasser (2007a). "The AFm phase in Portland cement." $\begin{array}{llll}\text { Cement and Concrete } & \text { Research } & \text { 118-130, }\end{array}$ https://doi.org/10.1016/j.cemconres.2006.10.010.

Matschei, T., B. Lothenbach and F. P. Glasser (2007b). "Thermodynamic properties of Portland cement hydrates in the system $\mathrm{CaO}-\mathrm{Al}_{2} \mathrm{O}_{3}-\mathrm{SiO}_{2}-\mathrm{CaSO}_{4}-\mathrm{CaCO}_{3}-\mathrm{H}_{2} \mathrm{O}$." Cement and Concrete Research 37(10): 1379-1410, https://doi.org/10.1016/j.cemconres.2007.06.002.

Mesbah, A., M. François, C. Cau-dit-Coumes, F. Frizon, Y. Filinchuk, F. Leroux, J. Ravaux and G. Renaudin (2011a). "Crystal structure of Kuzel's salt $3 \mathrm{CaO} \cdot \mathrm{Al}_{2} \mathrm{O}_{3} \cdot 1 / 2 \mathrm{CaSO}_{4} \cdot 1 / 2 \mathrm{CaCl}_{2}$. $11 \mathrm{H}_{2} \mathrm{O}$ determined by synchrotron powder diffraction." Cement and Concrete Research 41(5): 504-509, https://doi.org/10.1016/j.cemconres.2011.01.015.

Mesbah, A., C. Cau-dit-Coumes, F. Frizon, F. Leroux, J. Ravaux and G. Renaudin (2011b). "A new investigation of the $\mathrm{Cl}^{-}-\mathrm{CO}_{3}{ }^{2-}$ substitution in AFm phases." Journal of the American Ceramic Society 94(6): 1901-1910, https://doi.org/10.1111/j.1551-2916.2010.04305.x.

Momma, K. and F. Izumi (2008). "VESTA: a three-dimensional visualization system for electronic and structural analysis." Journal of Applied Crystallography 41(3): 653-658, https://doi.org/10.1107/S0021889808012016.

NAGRA (2002). Demonstration of disposal feasibility for spent fuel, vitrified high-level waste and long-lived intermediate level waste, Nagra Technical Report NTB 02-05. Nagra, Wettingen, Switzerland.

Nedyalkova, L., B. Lothenbach, G. Renaudin, U. Mäder and J. Tits (2019). "Effect of redox conditions on the structure and solubility of sulfur- and selenium-AFm phases." Cement and Concrete Research 123: 105803, https://doi.org/10.1016/j.cemconres.2019.105803.

Pöllmann, H. (2006). "Syntheses, properties and solid solution of ternary lamellar calcium aluminate hydroxi salts (AFm-phases) containing $\mathrm{SO}_{4}{ }^{2-}, \mathrm{CO}_{3}{ }^{2-}$ and $\mathrm{OH}^{-}$." Neues Jahrbuch für Mineralogie-Abhandlungen: Journal of Mineralogy and Geochemistry 182(2): 173-181, https://doi.org/10.1127/0077-7757/2006/0042.

Rapin, J.-P., A. Walcarius, G. Lefevre and M. Francois (1999). "A double-layered hydroxide, 3CaO. $\mathrm{Al}_{2} \mathrm{O}_{3}$. $\mathrm{CaI}_{2}$. 10H $\mathrm{H}_{2} \mathrm{O}$." Acta Crystallographica Section C: Crystal Structure Communications 55(12): 1957-1959, https://doi.org/10.1107/S0108270199008665.

Redlich, O. and A. Kister (1948). "Algebraic representation of thermodynamic properties and the classification of solutions." Industrial \& Engineering Chemistry 40(2): 345-348, https://doi.org/10.1021/ie50458a036. 
Renaudin, G., M. Francois and O. Evrard (1999). "Order and disorder in the lamellar hydrated tetracalcium monocarboaluminate compound." Cement and Concrete Research 29(1): 63-69, https://doi.org/10.1016/S0008-8846(98)00184-7.

Renaudin, G., A. Mesbah, B. Dilnesa, M. Francois and B. Lothenbach (2015). "Crystal chemistry of iron containing cementitious AFm layered hydrates." Current Inorganic Chemistry 5(3): 184-193, https://doi.org/10.2174/1877944105666150420235831.

Runčevski, T., R. E. Dinnebier, O. V. Magdysyuk and H. Pöllmann (2012). "Crystal structures of calcium hemicarboaluminate and carbonated calcium hemicarboaluminate from synchrotron powder diffraction data." Acta Crystallographica Section B: Structural Science 68(5): 493-500, https://doi.org/10.1107/S010876811203042X.

Taylor, H. F. (1997). Cement chemistry, Thomas Telford.

Terzis, A., S. Filippakis, H.-J. Kuzel and H. Burzlaff (1987). "The crystal structure of $\mathrm{Ca}_{2} \mathrm{Al}(\mathrm{OH})_{6} \mathrm{Cl} \cdot 2 \mathrm{H}_{2} \mathrm{O}$." Zeitschrift für Kristallographie-Crystalline Materials 181(1-4): 29-34, https://doi.org/10.1524/zkri.1987.181.14.29.

Thoenen, T., W. Hummel, U. Berner and E. Curti (2014). "The PSI/Nagra chemical thermodynamic database 12/07." PSI report 14-04: 14-49.

Toyohara, M., M. Kaneko, H. Ueda, N. Mitsutsuka, H. Fujihara, T. Murase and N. Saito (2000). "Iodine sorption onto mixed solid alumina cement and calcium compounds." Journal of Nuclear Science and Technology 37(11): 970-978, https://doi.org/10.1080/18811248.2000.9714980.

Traynor, B., H. Uvegi, E. Olivetti, B. Lothenbach and R. J. Myers (2019). "Methodology for pH measurement in high alkali cementitious systems." Cement and Concrete Research submitted.

Vanselow, A. P. (1932). "Equilibria of the base-exchange reactions of bentonites, permutites, soil colloids, and zeolites." Soil Science 33(2): 95-114, https://doi.org/10.1097/00010694193202000-00002.

Wersin, P., L. H. Johnson, B. Schwyn, U. Berner and E. Curti (2003). Redox conditions in the near field of a repository for SF/HLW and ILW in Opalinus clay, Nagra Technical Report NTB 02-13. Nagra, Wettingen, Switzerland.

Zajac, M., A. Rossberg, G. Le Saout and B. Lothenbach (2014). "Influence of limestone and anhydrite on the hydration of Portland cements." Cement and Concrete Composites 46: 99-108, https://doi.org/10.1016/j.cemconcomp.2013.11.007.

Zhang, M. (2000). "Incorporation of oxyanionic B, Cr, Mo, and Se into hydrocalumite and ettringite, application to cementitious systems." $\mathrm{PhD}$ Thesis at the University of Waterloo, Ontario, Canada. 


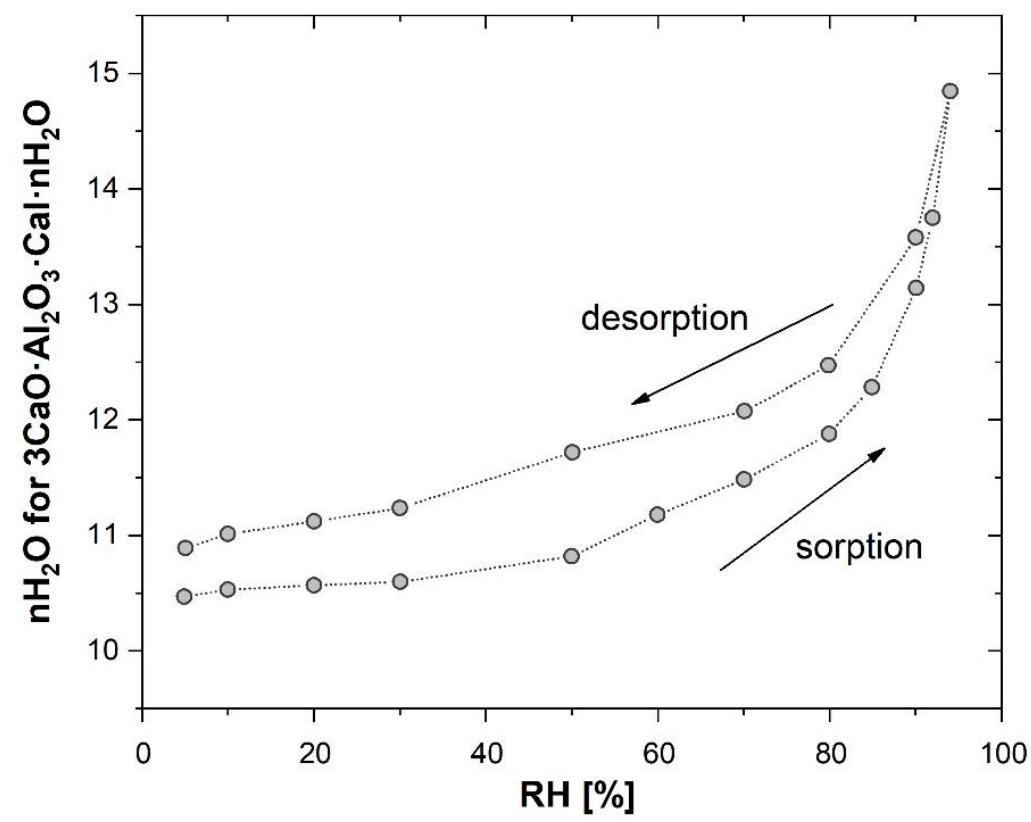

Figure A.1: Sorption isotherm for monoiodide (pH 13) measured at $25^{\circ} \mathrm{C}$ on a VTI-SA Dynamic Vapour Sorption (DVS) apparatus (TA Inc, USA). The relative humidity (RH) was varied between 5 and $95 \%$. The graph was normalized to $10 \mathrm{H}_{2} \mathrm{O}$ based on the structure reported for monoiodide (Rapin et al. 1999). 
(a) (I,OH)-AFm ss pH 13

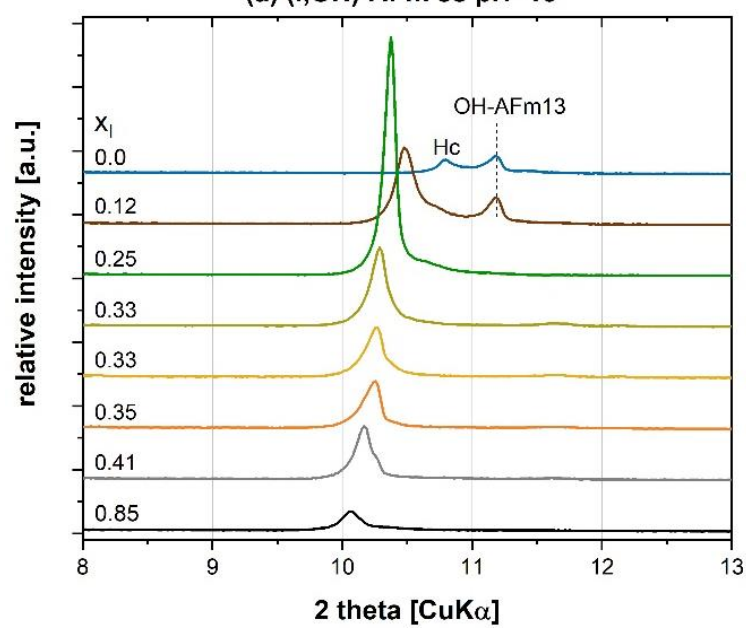

(c) (I,Mc)-AFm ss pH 13

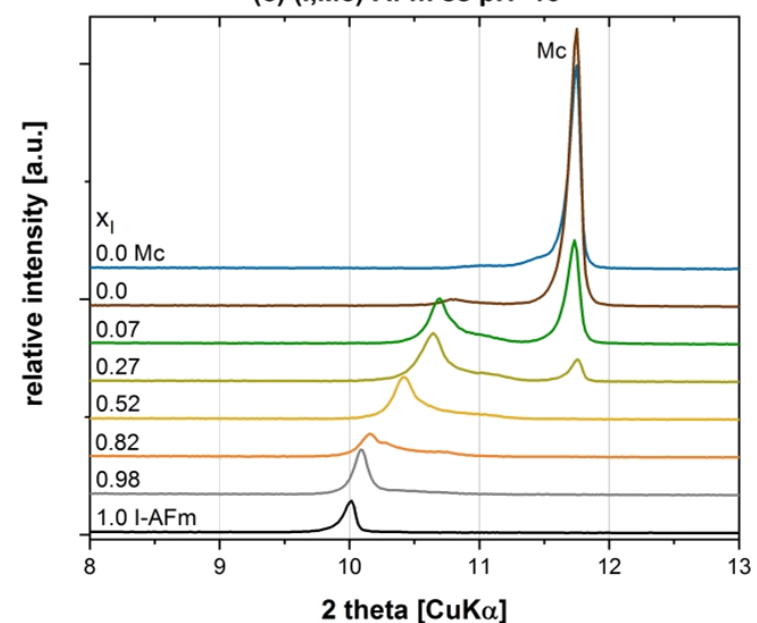

(b) $(\mathrm{I}, \mathrm{Hc})$-AFm ss $\mathrm{pH} 13$

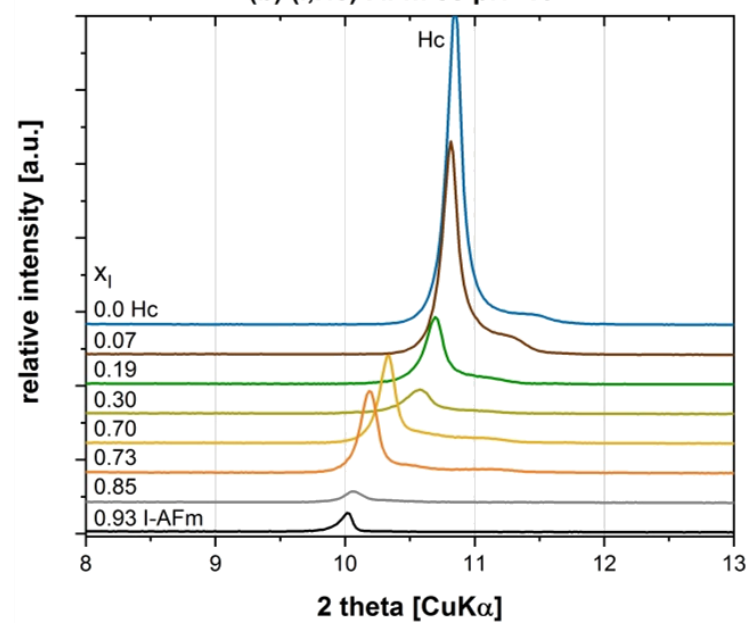

(d) (I,Mc)-AFm ss pH 13

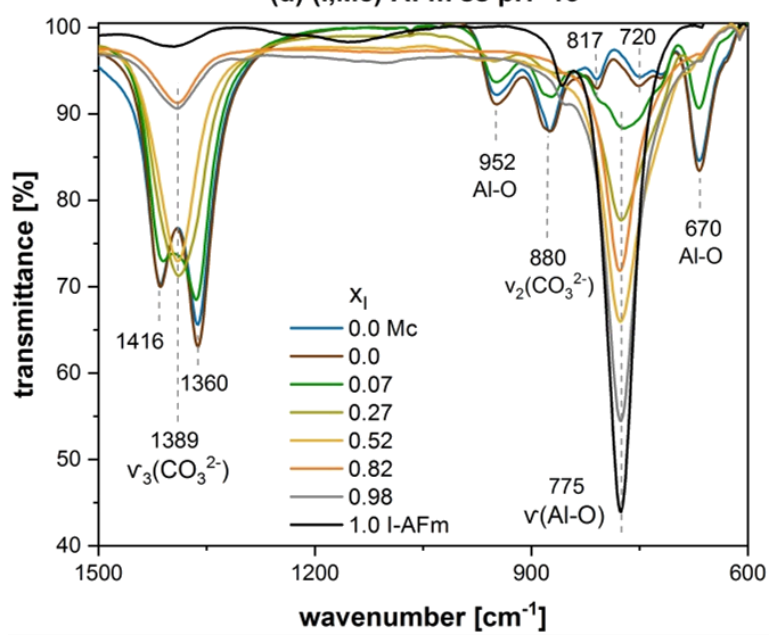

776

Table A.1: Dissolution reactions used to calculate the solubility products $\left(\log \mathrm{K}_{\mathrm{s} 0}\right)$.

\begin{tabular}{|c|c|c|c|}
\hline Phase & Dissolution reaction & & $\begin{array}{l}\log \mathrm{K}_{\mathrm{s} 0} \\
20^{\circ} \mathrm{C}\end{array}$ \\
\hline monoiodide & $\mathrm{Ca}_{4} \mathrm{Al}_{2} \mathrm{I}_{2}(\mathrm{OH})_{12} \cdot 9 \mathrm{H}_{2} \mathrm{O}$ & $\begin{array}{l}\rightarrow 4 \mathrm{Ca}^{2+}+2 \mathrm{AlO}_{2}^{-}+2 \mathrm{I}^{-}+4 \mathrm{OH}^{-}+ \\
13 \mathrm{H}_{2} \mathrm{O}\end{array}$ & $-27.6 \pm 0.1$ \\
\hline hydroxy-AFm & $\mathrm{Ca}_{4} \mathrm{Al}_{2}(\mathrm{OH})_{14} \cdot 12 \mathrm{H}_{2} \mathrm{O}$ & $\rightarrow 4 \mathrm{Ca}^{2+}+2 \mathrm{AlO}_{2}^{-}+6 \mathrm{OH}^{-}+16 \mathrm{H}_{2} \mathrm{O}$ & $-26.4 \pm 2.0$ \\
\hline hemicarbonate & $\mathrm{Ca}_{4} \mathrm{Al}_{2}\left(\mathrm{CO}_{3}\right)_{0.5}(\mathrm{OH})_{13} \cdot 5.5 \mathrm{H}_{2} \mathrm{O}$ & $\begin{array}{l}\rightarrow 4 \mathrm{Ca}^{2+}+2 \mathrm{AlO}_{2}^{-}+0.5\left(\mathrm{CO}_{3}\right)^{2-}+ \\
5 \mathrm{OH}^{-}+9.5 \mathrm{H}_{2} \mathrm{O}\end{array}$ & $-29.1 \pm 0.3$ \\
\hline monocarbonate & $\mathrm{Ca}_{4} \mathrm{Al}_{2}\left(\mathrm{CO}_{3}\right)(\mathrm{OH})_{12} \cdot 5 \mathrm{H}_{2} \mathrm{O}$ & $\begin{array}{l}\rightarrow 4 \mathrm{Ca}^{2+}+2 \mathrm{AlO}_{2}^{-}+\mathrm{CO}_{3}^{2-}+4 \mathrm{OH}^{-}+ \\
9 \mathrm{H}_{2} \mathrm{O}\end{array}$ & $-30.2 \pm 0.8$ \\
\hline
\end{tabular}

Figure A.2: XRPD pattern of the monoiodide-hydroxy-AFm (a), monoiodide-hemicarbonate (b) and monoiodide-monocarbonate-AFm (c) solid solution series synthesized at $\mathrm{pH} \sim 13$ and $20^{\circ} \mathrm{C}$; (d) FTIR spectra of the monoiodide-monocarbonate-AFm series showing the splitting of the $v_{3}\left(\mathrm{CO}_{3}{ }^{2-}\right)$ band with the appearance of monocarbonate. Hc: hemicarbonate, I-AFm: monoiodide, Mc: monocarbonate, OH-AFm13: hydroxy-AFm with $13 \mathrm{H}_{2} \mathrm{O}$. 
Table A.2: Refinement results for the samples belonging to the monoiodide-hemicarbonateAFm solid solution series synthesized at $\mathrm{pH} \sim 12$.

\begin{tabular}{cccccccc}
\hline nominal $\mathrm{x}_{\mathrm{I}}$ & refined $\mathrm{x}_{\mathrm{I}}$ & $\begin{array}{c}a \\
{[\AA]}\end{array}$ & $\begin{array}{c}c \\
{[\AA]}\end{array}$ & $\begin{array}{c}(\mathrm{I}, \mathrm{Hc})-\mathrm{AFm} \\
{[\%]}\end{array}$ & $\begin{array}{c}\text { katoite } \\
{[\%]}\end{array}$ & $\begin{array}{c}\mathrm{cHc} \\
{[\%]}\end{array}$ & $\begin{array}{c}\mathrm{Mc} \\
{[\%]}\end{array}$ \\
\hline & & & & & & \\
0.0 & $0.00 \pm 0.00$ & $5.76 \pm 0.001$ & $48.88 \pm 0.003$ & $50 \pm 5$ & $9 \pm 2$ & $25 \pm 5$ & $16 \pm 5$ \\
0.1 & $0.16 \pm 0.05$ & $5.76 \pm 0.001$ & $49.37 \pm 0.005$ & $58 \pm 5$ & $11 \pm 2$ & $18 \pm 5$ & $13 \pm 5$ \\
0.3 & $0.39 \pm 0.05$ & $5.77 \pm 0.001$ & $50.56 \pm 0.006$ & $53 \pm 10$ & $6 \pm 2$ & $41 \pm 15$ & $0 \pm 2$ \\
0.5 & $0.63 \pm 0.03$ & $5.77 \pm 0.000$ & $51.92 \pm 0.003$ & $86 \pm 5$ & $2 \pm 2$ & $12 \pm 5$ & $0 \pm 2$ \\
0.7 & $0.76 \pm 0.03$ & $5.77 \pm 0.001$ & $52.68 \pm 0.005$ & $100 \pm 2$ & $0 \pm 0$ & $0 \pm 2$ & $0 \pm 0$ \\
0.9 & $0.90 \pm 0.03$ & $5.78 \pm 0.000$ & $53.07 \pm 0.002$ & $100 \pm 2$ & $0 \pm 0$ & $0 \pm 2$ & $0 \pm 0$ \\
1.0 & $0.93 \pm 0.03$ & $5.77 \pm 0.000$ & $53.10 \pm 0.003$ & $100 \pm 0$ & $0 \pm 0$ & $0 \pm 0$ & $0 \pm 0$ \\
\hline
\end{tabular}

788

789

790

791

Table A.3: Liquid phase analysis of the samples belonging to the monoiodide-hydroxy-AFm solid solution series.

\begin{tabular}{cccccccc}
\hline $\begin{array}{c}\text { Sample } \\
x_{\mathrm{I}}\end{array}$ & $\begin{array}{c}\text { Eq. Time } \\
{[\mathrm{d}]}\end{array}$ & $\begin{array}{c}\mathrm{pH} \\
20^{\circ} \mathrm{C}\end{array}$ & $\begin{array}{c}\mathrm{Al} \\
{[\mathrm{mmol} / \mathrm{l}]}\end{array}$ & $\begin{array}{c}\mathrm{Ca} \\
{[\mathrm{mmol} / \mathrm{l}]}\end{array}$ & $\begin{array}{c}\mathrm{I} \\
{[\mathrm{mmol} / \mathrm{l}]}\end{array}$ & $\begin{array}{c}\mathrm{Na} \\
{[\mathrm{mmol} / \mathrm{l}]}\end{array}$ & $\begin{array}{c}\mathrm{OH} \\
{[\mathrm{mmol} / \mathrm{l}]}\end{array}$ \\
\hline & & & & & & & \\
0.76 & 90 & 12.3 & 0.036 & 12.39 & 32.17 & 20.14 & 16.47 \\
0.48 & 90 & 12.7 & 0.009 & 8.20 & 33.29 & 60.26 & 38.83 \\
0.32 & 90 & 12.9 & 0.014 & 4.72 & 19.54 & 99.19 & 67.02 \\
0.25 & 90 & 13.1 & 0.152 & 2.23 & 10.31 & 143.9 & 91.54 \\
0.13 & 90 & 13.1 & 0.262 & 1.65 & 5.98 & 183.8 & 111.2 \\
& & & & & & & \\
0.35 & 90 & 13.0 & 0.120 & 2.03 & 83.08 & 216.7 & 84.68 \\
0.33 & 90 & 13.1 & 0.068 & 2.33 & 52.22 & 215.5 & 98.97 \\
0.33 & 90 & 13.1 & 0.195 & 1.66 & 21.85 & 208.3 & 111.2 \\
0.25 & 90 & 13.1 & 0.309 & 1.61 & 11.19 & 208.4 & 115.7 \\
0.12 & 90 & 13.1 & 0.325 & 1.78 & 6.62 & 203.0 & 107.0 \\
\hline
\end{tabular}

792

793

Table A.4: Liquid phase analysis of the samples belonging to the monoiodide-hemicarbonate solid solution series.

\begin{tabular}{|c|c|c|c|c|c|c|c|c|}
\hline $\begin{array}{c}\text { Sample } \\
x_{\text {I }} \\
\end{array}$ & $\begin{array}{c}\text { Eq. Time } \\
{[\mathrm{d}]}\end{array}$ & $\begin{array}{c}\mathrm{pH} \\
20^{\circ} \mathrm{C} \\
\end{array}$ & $\begin{array}{c}\mathrm{Al} \\
{[\mathrm{mmol} / \mathrm{l}]}\end{array}$ & $\begin{array}{c}\mathrm{Ca} \\
{[\mathrm{mmol} / \mathrm{l}]}\end{array}$ & $\begin{array}{c}\mathrm{I} \\
{[\mathrm{mmol} / \mathrm{l}]}\end{array}$ & $\begin{array}{c}\mathrm{C} \\
{[\mathrm{mmol} / \mathrm{l}]}\end{array}$ & $\begin{array}{c}\mathrm{Na} \\
{[\mathrm{mmol} / \mathrm{l}]}\end{array}$ & $\begin{array}{c}\mathrm{OH} \\
{[\mathrm{mmol} / \mathrm{l}]}\end{array}$ \\
\hline 0.90 & 90 & 11.7 & 2.51 & 12.49 & 17.19 & 0.081 & 0.459 & 4.45 \\
\hline 0.76 & 90 & 11.9 & 2.45 & 10.11 & 10.62 & 0.084 & 0.496 & 6.55 \\
\hline 0.63 & 90 & 12.0 & 1.40 & 9.13 & 6.97 & 0.022 & 0.492 & 9.27 \\
\hline 0.39 & 90 & 12.3 & 0.040 & 16.16 & 8.98 & 0.017 & 0.480 & 17.87 \\
\hline 0.16 & 90 & 12.5 & 0.009 & 18.24 & 2.18 & 0.006 & 0.503 & 27.33 \\
\hline 0.73 & 90 & 13.0 & 0.181 & 2.28 & 87.74 & $<.01$ & 216.2 & 88.43 \\
\hline
\end{tabular}




\begin{tabular}{lllllllll}
0.70 & 90 & 13.1 & 0.173 & 1.31 & 68.23 & $<.01$ & 216.4 & 103.8 \\
0.30 & 90 & 13.1 & 0.102 & 3.32 & 46.02 & $<.01$ & 216.4 & 112.4 \\
0.19 & 90 & 13.1 & 0.096 & 2.69 & 25.51 & $<.01$ & 220.7 & 121.7 \\
0.07 & 90 & 13.2 & 0.081 & 1.90 & 8.835 & $<.01$ & 209.4 & 131.9 \\
\hline
\end{tabular}

796

797

798 Table A.5: Liquid phase analysis of the samples belonging to the monoiodide-monocarbonate 799 solid solution series.

\begin{tabular}{ccccccccc}
\hline $\begin{array}{c}\text { Sample } \\
x_{\mathrm{I}}\end{array}$ & $\begin{array}{c}\mathrm{Eq} \text {. Time } \\
{[\mathrm{d}]}\end{array}$ & $\begin{array}{c}\mathrm{pH} \\
20^{\circ} \mathrm{C}\end{array}$ & $\begin{array}{c}\mathrm{Al} \\
{[\mathrm{mmol} / \mathrm{l}]}\end{array}$ & $\begin{array}{c}\mathrm{Ca} \\
{[\mathrm{mmol} / \mathrm{l}]}\end{array}$ & $\begin{array}{c}\mathrm{I} \\
{[\mathrm{mmol} / \mathrm{l}]}\end{array}$ & $\begin{array}{c}\mathrm{C} \\
{[\mathrm{mmol} / \mathrm{l}]}\end{array}$ & $\begin{array}{c}\mathrm{Na} \\
{[\mathrm{mmol} / \mathrm{l}]}\end{array}$ & $\begin{array}{c}\mathrm{OH} \\
{[\mathrm{mmol} / \mathrm{l}]}\end{array}$ \\
\hline & & & & & & & & \\
0.94 & 90 & 11.6 & 3.06 & 13.64 & 21.57 & 0.081 & 0.461 & 3.08 \\
0.81 & 90 & 11.7 & 4.01 & 10.17 & 11.87 & 0.077 & 0.443 & 4.38 \\
0.65 & 90 & 11.9 & 3.31 & 9.11 & 9.11 & 0.057 & 0.468 & 6.22 \\
0.44 & 90 & 12.0 & 2.72 & 7.87 & 5.74 & 0.027 & 0.456 & 8.83 \\
0.09 & 90 & 12.0 & 3.65 & 5.59 & 3.77 & 0.025 & 0.498 & 7.85 \\
& & & & & & & & \\
0.82 & 90 & 13.0 & 0.080 & 3.92 & 97.63 & $<.01$ & 213.2 & 95.06 \\
0.52 & 90 & 13.0 & 0.166 & 3.99 & 88.20 & $<.01$ & 214.0 & 95.06 \\
0.27 & 90 & 13.0 & 0.186 & 3.29 & 72.91 & $<.01$ & 217.9 & 98.77 \\
0.07 & 90 & 13.0 & 0.070 & 2.99 & 53.12 & $<.01$ & 212.8 & 106.6 \\
0.0 & 90 & 13.1 & 0.566 & 0.681 & 20.65 & $<.01$ & 209.5 & 119.7 \\
\hline
\end{tabular}

800 